\title{
"Catch-and-Release" Anti-Carcinoembryonic Antigen Monoclonal Antibody Leads to Greater Plasma and Tumor Exposure in a Mouse Model of Colorectal Cancer
}

\author{
Frank A. Engler, Joseph Ryan Polli, Tommy Li, Bo An, Michael Otteneder, Jun Qu, \\ and Joseph P. Balthasar
}

Department of Pharmaceutical Sciences, School of Pharmacy and Pharmaceutical Sciences, University at Buffalo (F.A.E., J.R.P., T.L., B.A., J.Q., J.P.B.) and New York State Center of Excellence in Bioinformatics and Life Sciences (B.A., J.Q.), Buffalo, New York; and F. Hoffmann-La Roche Ltd., Roche Innovation Center, Basel, Switzerland (M.O.)

Received December 2, 2017; accepted May 1, 2018

\begin{abstract}
In this study, we examined the effects of target expression, neonatal Fc receptor ( $\mathrm{FcRn}$ ) expression in tumors, and $\mathrm{pH}$-dependent target binding on the disposition of monoclonal antibodies (mAbs) in murine models of colorectal cancer. A panel of anti-carcinoembryonic antigen (CEA) mAbs was developed via standard hybridoma technology and then evaluated for $\mathrm{pH}$-dependent CEA binding. Binding was assessed via immunoassay and radioligand binding assays. $10 \mathrm{H} 6$, a murine $\lg \mathrm{G} 1$ $\mathrm{mAb}$ with high affinity for $\mathrm{CEA}$ at $\mathrm{pH}=7.4\left(K_{\mathrm{D}}=12.6 \pm 1.7 \mathrm{nM}\right)$ and reduced affinity at $\mathrm{pH}=6.0\left(K_{\mathrm{D}}=144.6 \pm 21.8 \mathrm{nM}\right)$, and T84.66, which exhibits $\mathrm{pH}$-independent CEA binding $\left(K_{\mathrm{D}}=1.1 \pm\right.$ 0.11 and $1.4 \pm 0.16 \mathrm{nM}$ at $\mathrm{pH} 7.4$ and 6.0 ), were selected for pharmacokinetic investigations. We evaluated pharmacokinetics after intravenous administration to control mice and to mice bearing tumors with (MC38 $\left.{ }^{\mathrm{CEA}+}, \mathrm{LS} 174 \mathrm{~T}\right)$ and without $\left(\mathrm{MC}_{3} 8^{\mathrm{CEA}-}\right) \mathrm{CEA}$ expression and with or without expression

of murine FcRn, at doses of $0.1,1$, and $10 \mathrm{mg} / \mathrm{kg}$. $10 \mathrm{H} 6$ displayed linear pharmacokinetics in mice bearing MC38 CEA+ or MC38 ${ }^{\mathrm{CEA}-}$ tumors. T84.66 displayed linear pharmacokinetics in mice with MC38 CEA- tumors but dose-dependent nonlinear pharmacokinetics in mice bearing $\mathrm{MC} 38^{\mathrm{CEA}+}$. In addition to the improved plasma pharmacokinetic profile (i.e., linear pharmacokinetics, longer terminal half-life), $10 \mathrm{H} 6$ exhibited improved exposure in $\mathrm{MC} 38^{\mathrm{CEA}+}$ tumors relative to T84.66. In mice bearing tumors with CEA expression, but lacking expression of murine FcRn (LS174T), 10H6 demonstrated nonlinear pharmacokinetics, with rapid clearance at low dose. These data are consistent with the hypothesis that $\mathrm{pH}$-dependent CEA binding allows mAb dissociation from target in acidified endosomes, enabling FcRn-mediated protection from target-mediated elimination in mice bearing

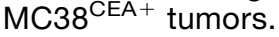

\section{Introduction}

Currently, 23 monoclonal antibodies (mAbs) have been approved by the Food and Drug Administration for cancer indications, and many more are in late stages of clinical development (Reichert, 2012, 2016, 2017; Ecker et al., 2015). The market for mAbs is rapidly expanding, with projected worldwide sales of $\$ 125$ billion by 2020 (Ecker et al., 2015). With increased development of $\mathrm{mAb}$ drugs, there is increasing interest in optimization strategies, including efforts to engineer mAbs for improved stability, pharmacokinetics, and pharmacodynamics (Beck et al., 2010). Optimization of pharmacokinetics has focused primarily on engineering mAbs for higher-affinity binding to the $\mathrm{Fc}$ receptor of the neonate, $\mathrm{FcRn}$,

This work was funded by the National Institutes of Health/National Cancer Institute [Grant 1R01CA204192] and by F. Hoffmann-La Roche Ltd.

https://doi.org/10.1124/jpet.117.246900. which protects IgG antibodies from intracellular catabolism (Hinton et al., 2004; Dall'Acqua et al., 2006) or engineering mAb molecular charge (Boswell et al., 2010); however, there has been growing interest in the development of mAbs with $\mathrm{pH}$-dependent target binding that allows efficient target binding at physiologic $\mathrm{pH}$, but where $\mathrm{mAb}$-target binding is substantially reduced at acidic $\mathrm{pH}$. This $\mathrm{pH}$-dependent binding allows mAbs to bind (i.e., "catch") target in extracellular fluid but also to release target in the acidic environment of endosomes. After release from target, the unbound $\mathrm{mAb}$ may be salvaged from intracellular catabolism via transport mediated by $\mathrm{FcRn}$. In some cases, $\mathrm{pH}$-dependent binding decreased the efficiency of target-mediated mAb elimination, decreasing $\mathrm{mAb}$ clearance, extending exposure, and enhancing the extent and duration of mAb effects (Igawa et al., 2010; Chaparro-Riggers et al., 2012).

Junghans and Anderson (1996) hypothesized that catchand-release (CAR) binding and FcRn-mediated recycling of

ABBREVIATIONS: ANOVA, analysis of variance; AP, alkaline phosphatase; BSA, bovine serum albumin; CAR, catch-and-release; CEA, carcinoembryonic antigen; CL, clearance; ELISA, enzyme-linked immunosorbent assay; FcRn, neonatal Fc receptor; IL2R, interleukin-2 receptor; $K_{\mathrm{D}}$, equilibrium binding dissociation constant; LC-MS/MS, liquid chromatography-tandem mass spectrometry; LOQ, limit of quantification; mAb, monoclonal antibody; MFI, mean fluorescence intensity; NCA, noncompartmental analysis; PBS, phosphate-buffered saline; PNPP, $p$-nitro phenyl phosphate; QC, quality control; TCA, trichloroacetic acid; $V_{\mathrm{ss}}$, volume of distribution at steady-state. 
unbound mAb could explain observations made after the administration of anti-interleukin-2 receptor (IL2R) mAbs in wild-type and FcRn-knockout mice (Junghans and Waldmann, 1996). In FcRn-knockout mice, they found that the receptor and the antibody demonstrated similar rates of elimination, but they found that the receptor was eliminated more rapidly than the antibody in wild-type mice (with functional expression of $\mathrm{FcRn}$ ). They hypothesized that mAb-IL2R complexes are endocytosed, with dissociation of $\mathrm{mAb}$ from IL2R in the acidic environment of the endosome. In the presence of functional $\mathrm{FcRn}, \mathrm{mAb}$ is transported out of the cell, whereas in the absence of functional FcRn, the $\mathrm{mAb}$ and receptor are delivered to the lysosome for catabolism.

CAR mAb binding may be mediated through ionization of histidine residues. Histidine has a $\mathrm{pKa}$ of $\sim 6$, and it is the only naturally occurring amino acid that protonates in the range of endosomal acidification ( $\mathrm{pH}$ 7.4-5.5) (Markley, 1975; Geisow and Evans, 1984). This unique behavior makes it critically important to many naturally occurring $\mathrm{pH}$-triggered proteinprotein interactions (Vaughn and Bjorkman, 1998). Histidine protonation may act to stabilize or to destabilize mAb-ligand binding sites, either by direct charge attraction or charge repulsion or via less direct effects, perhaps by effects of histidine protonation on the tertiary structure of the protein (Vaughn and Bjorkman, 1998). Several groups have engineered $\mathrm{mAbs}$ for CAR binding by replacing residues in or near the mAb-ligand binding pocket with histidine (i.e., "histidine switching”) (Igawa et al., 2010; Chaparro-Riggers et al., 2012). In two recent examples, mAbs were developed for CAR binding to IL6R and to PCSK9, where the mAbs were engineered with a $\sim 10$-fold decrease in affinity at $\mathrm{pH}$ of 6.0 relative to $\mathrm{pH}$ 7.4. In each case, the $\mathrm{CAR} \mathrm{mAb}$ demonstrated a dramatic reduction in target mediated elimination compared with "standard" mAb (i.e., mAb that exhibit high affinity binding across the $\mathrm{pH}$ range of 5.5-7.4).

Carcinoembryonic antigen (CEA, CEACAM5, or CD66e) is a highly glycosylated $180-\mathrm{kDa}$ cell-surface glycoprotein that is expressed on the luminal side of the colon in healthy adults (Hammarstrom, 1999). The primary role of CEA is thought to be mediation of cellular contact by either homophilic or heterophilic intercellular binding mechanisms (Zheng et al., 2011). CEA can internalize mAbs with an uptake half-life of 10-16 hours (Schmidt et al., 2008). Many types of cancers show a substantial overexpression of CEA (Hammarstrom, 1999), and CEA overexpression has been found in $~ 90 \%$ of colorectal tumors (Goldstein and Mitchell, 2005). The selective overexpression of CEA has led to significant interest in developing anti-CEA mAb for imaging and treatment (Mach et al., 1981; Rowland et al., 1986; Baum et al., 1989; KraeberBodéré et al., 2006; Shin et al., 2015).

The purpose of the present work is to examine the plasma pharmacokinetics of a newly developed anti-CEA CAR antibody, 10H6, in a mouse model of colorectal cancer, with comparison of results to those found for an anti-CEA $\mathrm{mAb}$ that exhibits pH-independent binding (T84.66).

\section{Materials and Methods}

\section{CEA Immunization}

Three female BALB/c (Harlan, Indianapolis, IN) mice were immunized with $100 \mu \mathrm{l}$ of emulsified CEA (cat. no. 151-10; Lee Bio Solutions,
St. Louis, MO). CEA emulsification was prepared by dilution of $50 \mu \mathrm{g}$ of CEA in $50 \mu \mathrm{l}$ of phosphate-buffered saline and subsequent emulsification with an equal volume of Freund's incomplete adjuvant (cat. no. D2650; Sigma, St. Louis, MO). Mice were boosted with emulsified CEA at 3 and 6 weeks. One week after the last booster injection, mouse blood was sampled, and mouse plasma was assayed for anti-CEA activity with an antigen-capture enzyme-linked immunosorbent assay (ELISA). The mouse with the highest assay signal was chosen for fusion and given a final i.p. injection of $50 \mu \mathrm{g}$ of CEA in $100 \mu \mathrm{l}$ of isotonic saline.

\section{Antigen-Capture ELISA for the Detection of Anti-CEA IgG Binding}

An antigen (CEA) captured ELISA was developed to quantify antiCEA antibody in both plasma and cell culture media, as well as to assess pH-dependent binding. Briefly, ELISA plate (cat. no. 62409002; VWR, Bridgeport, NJ) wells were coated with $250 \mu \mathrm{l}$ of $3 \mu \mathrm{g} / \mathrm{ml}$ of CEA in $0.02 \mathrm{M} \mathrm{Na}_{2} \mathrm{HPO}_{4}$ (no pH adjustment) for 2 hours at $37^{\circ} \mathrm{C}$. ELISA plates were washed three times with $0.05 \%$ Tween in $0.02 \mathrm{M}$ $\mathrm{Na}_{2} \mathrm{HPO}_{4}$ and then three times with $\mathrm{diH}_{2} \mathrm{O}$. Samples $(100 \mu \mathrm{l}$ of either plasma diluted 100-fold in pH $7.41 \times$ phosphate-buffered saline (PBS) or $100 \mu \mathrm{l}$ of cell culture media) were then dispensed on the plate and allowed to incubate for 2 hours at room temperature. Plates were washed as described previously and then incubated for 1 hour with PB-Tween (20 mM Na $2 \mathrm{PO}_{4}, 0.05 \%$ Tween) containing $0.2 \% \mathrm{v} / \mathrm{v}$ alkaline phosphatase (AP) conjugated to murine Fc-specific goat secondary IgG and $3 \% \mathrm{v} / \mathrm{v}$ bovine serum albumin (BSA) $(30 \% \mathrm{v} / \mathrm{v}$, cat. no. A1317; US Biologic, Salem, MA). After the final plate wash, $200 \mu \mathrm{l}$ of freshly prepared $4 \mathrm{mg} / \mathrm{ml} p$-nitro phenyl phosphate (PNPP) (cat. no. 34045; Pierce, Rockford, IL) in pH 9.8 diethanolamine buffer (cat. no. 34064; Pierce) was added to each well. The change in absorbance with time $(\mathrm{dA} / \mathrm{dt})$ at $405 \mathrm{~nm}$ was assessed using a Spectra Max 340 plate reader (Molecular Devices, Sunnyvale, CA).

\section{Anti-CEA Hybridoma Development}

The mouse with the highest level of anti-CEA IgG in plasma was selected for hybridoma development. Briefly, $5 \times 10^{6} \mathrm{SP} 2 / 0-\mathrm{Ag}$ 14 myeloma cells (ATC, Manassas, VA) were transferred to RPMI1640 (cat. no. 11875; Life Technologies, Grand Island, NY), containing 20\% fetal bovine serum (FBS) (cat. no. 10082147; Life Technologies), and $2 \times$ oxaloacetate pyruvate insulin media supplement (OPI; cat. no. O5003; Sigma). Three days after the intraperitoneal booster dose, the mouse was euthanized, and the spleen was removed aseptically. Spleen tissue was teased apart with an 18-gauge needle, and the disrupted tissue was then mixed with $10 \mathrm{ml}$ of warmed RPMI1640 media. After centrifuging the spleen cell suspension and the myeloma cell suspension at $500 \mathrm{~g}$ for 5 minutes, both pellets were resuspended in warmed RPMI1640 media. The resuspended cells were then combined and centrifuged at $800 \mathrm{~g}$ for 5 minutes, and $1 \mathrm{ml}$ of $50 \%$ polyethylene glycol (cat. no. P7181; Sigma) was added dropwise to the pellet and then gently mixed before the addition of $10 \mathrm{ml}$ of prewarmed RPMI1640, which was slowly added and gently mixed over the course of 3 minutes. The mixture was then centrifuged, and the pellet was resuspended with $200 \mathrm{ml}$ of RPMI1640 media containing $20 \% \mathrm{FBS}, 1 \times$ OPI, HAT (hypoxanthine, aminopterin, and thymidine) (cat. no. H0262; Sigma), and $5 \mathrm{mg} /$ liter of gentamicin (cat no. 15710072; Life Technologies). The media was then dispensed (175 $\mu \mathrm{l} /$ well) into 96-well plates.

\section{Hybridoma Screening and Cloning}

The cell media supernatant of every well was tested via the antigencapture ELISA for anti-CEA IgG. In initial testing, media were pooled from eight wells. In cases where the pooled media provided a positive assay response (defined as a $\mathrm{dA} / \mathrm{dt}>3 \times$ blank media), individual wells were subsequently screened. Individual hybridoma colonies identified as positive for anti-CEA IgG were then cloned by the method of 
single-cell picking. Briefly, a small portion of cells from each well containing uncloned anti-CEA IgG-positive hybridoma cells was diluted and transferred to a sterile 96 -well plate lid. Single cells were identified under $40 \times$ magnification and transferred with a $2.5-\mu \mathrm{l}$ pipettor to individual wells of a 96-well plate (containing $175 \mu \mathrm{l}$ of fresh RPMI1640 cell culture media, with $20 \%$ FBS and $1 \times$ OPI). Individual cells divided until colonies became visible (10-14 days) before testing cell culture supernatant for anti-CEA IgG. This cloning process was then repeated to ensure monoclonality.

\section{Screening for pH-Dependent Antigen Binding}

Anti-CEA IgG antibodies were tested for $\mathrm{pH}$-dependent CEA binding with the use of the antigen capture ELISA. Hybridoma cell culture media for each antibody were $\mathrm{pH}$ adjusted to either 7.0 or 5.5 and then tested, in triplicate, for binding to CEA. Antibodies that showed a significant reduction in binding with decreased $\mathrm{pH}$ were then neutralized and retested. Briefly, antibody containing media was $\mathrm{pH}$-adjusted to 7.0 and 5.5. After 30 minutes, a portion of the $\mathrm{pH} 5.5$ media was $\mathrm{pH}$-adjusted back to 7.0. These samples were then tested via ELISA in triplicate. Results were compared by Student's twotailed $t$ test, with statistical significance assumed when $P \leq 0.05$.

Antibodies that demonstrated reversible $\mathrm{pH}$-dependent binding were then more fully characterized over a range of $\mathrm{pH}$. Hybridoma cell culture media were adjusted to $\mathrm{pH} 5.5,6.0,6.5$, and 7.8, with each $\mathrm{pH}$ tested by antigen capture ELISA in triplicate.

\section{IgG Protein G Purification}

A BioLogic medium-pressure chromatography system (Bio-Rad, Hercules, CA), using a 5-ml HiTrap Protein G HP column (GE Healthcare, Uppsala, Sweden), was used to purify anti-CEA mAbs from hybridoma cell culture media. Cell culture media was loaded onto the Protein G column, and then $20 \mathrm{mM} \mathrm{Na}_{2} \mathrm{HPO}_{4}$ buffer ( $\mathrm{pH} \mathrm{7.0)}$ was used to wash the column. IgG was then eluted from the column with $100 \mathrm{mM}$ glycine buffer ( $\mathrm{pH} 2.8$ ), and 3-ml fractions collected in glass test tubes were immediately neutralized with $100 \mu \mathrm{l}$ of $1 \mathrm{M}$ Tris buffer. A 10K MWCO Slide-A-Lyzer dialysis cassette (Pierce Biotechnology) was then used to buffer exchange purified IgG into $1 \times \mathrm{PBS}(\mathrm{pH} 7.4)$.

\section{Analysis of $10 \mathrm{H} 6$ Cellular CEA Binding by Flow Cytometry}

To test $10 \mathrm{H} 6$ for binding to membrane-bound cellular CEA, flow cytometry analyses were conducted. Two cell lines that express CEA were used: LS174T (no. CL-188; American Type Culture Collection, Manassas, VA), a human colon cancer cell line, and MC38 ${ }^{\mathrm{CEA}+}$ (received as a gift from Dr. Abdul-Wahid from the University of Toronto), a murine colorectal cancer cell line that is stably transfected

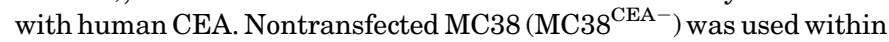
this experiment as a negative control. The high affinity anti-CEA IgG1 $\kappa$ mAb T84.66 (\#HB-8747; ATCC,) was used as a positive control for CEA binding. 8C2, an anti-topotecan IgG1 $\kappa$ (Chen and Balthasar, 2007; Shah and Balthasar, 2014), was used as a nonbinding isotype control. Flow cytometry experiments were conducted at room temperature and $\mathrm{pH} 7.4$ unless otherwise noted.

Briefly, cell lines were grown to $\sim 50 \%$ confluency, trypsinized, and harvested. After two successive washes with PBS containing $1 \mathrm{mM}$ EDTA, cells were counted and dispensed into $\sim 1 \times 10^{6}$ cell aliquots. Cells were then pelleted by centrifugation $(400 \mathrm{~g})$ and resuspended into $300 \mu \mathrm{l}$ of PBS containing $1 \mathrm{mM}$ EDTA and $1 \% \mathrm{v} / \mathrm{v}$ BSA to block nonspecific binding and incubated at $37^{\circ} \mathrm{C}$ for 15 minutes. After washing, cells were resuspended in $300 \mu \mathrm{l}$ of PBS with $1 \mathrm{mM}$ EDTA spiked with $1 \mu \mathrm{g}$ of primary antibody (10H6, T84.66, 8C2, or blank), gently agitated, and incubated for 30 minutes. Cells were then washed and blocked with PBS containing $1 \%$ v/v goat serum (cat. no. 16210064; Life Technologies) for 15 minutes at $37^{\circ} \mathrm{C}$. Cells were washed and then labeled with $300 \mu \mathrm{l}$ of PBS containing $1 \mathrm{mM}$ EDTA and phycoerythrin-conjugated goat anti-mouse IgG Fc (cat. no. 31861; Thermo Fisher Scientific, Rockford, IL) diluted 200:1 v/v for
30 minutes. Samples were washed and stored in $1 \mathrm{ml}$ of PBS with $1 \mathrm{mM}$ EDTA on ice and protected from light until flow cytometry analysis. A BD Fortessa SORP (BD Biosciences, San Jose, CA) flow cytometer was used to analyze all samples.

\section{Competitive ELISA to Assess pH-Dependent Binding}

A competitive ELISA was developed to assess the $\mathrm{pH}$-dependent binding of purified antibody. $10 \mathrm{H} 6$ and T84.66 were labeled with AP using a commercial kit from Abcam (Abcam, Cambridge, MA cat. no. ab102850). Nunc MaxiSorp flat-bottom 96-well ELISA plates were coated with $250 \mu \mathrm{l}$ of $1 \mu \mathrm{g} / \mathrm{ml}$ recombinant CEA overnight at $4^{\circ} \mathrm{C}$. After incubation, plates were washed with phosphate-buffered Tween three times followed by two washes of $\mathrm{diH}_{2} \mathrm{O}$. Experimental solutions of antibody were spiked with AP conjugate (1:5000-10,000). Samples were then added to each well in an amount of $250 \mu \mathrm{l}$, followed by a 2 -hour incubation at room temperature. After incubation, plates were washed according to the steps provided here. A solution of $4 \mathrm{mg} / \mathrm{ml}$ pNPP was made in $1 \times$ diethanolamine substrate buffer, $\mathrm{pH} 9.8$. Lastly, $250 \mu \mathrm{l}$ of pNPP solution was added to each well. Absorbance was measured at $405 \mathrm{~nm}$ immediately after the addition of pNPP mixture using the kinetic setting on a SpectraMax 340PC. Data were then fit to an inhibition function using ADAPT 5 (Biomedical Simulations Resource, USC, Los Angeles, CA) to obtain $K_{\mathrm{D}}$ values in eq. 1 :

$$
\% \text { Response }=100 \%-\frac{100 \% \cdot[\mathrm{mAb}]^{\gamma}}{\mathrm{K}_{\mathrm{D}}^{\gamma}+[\mathrm{mAb}]^{\gamma}} .
$$

\section{Preparation of ${ }^{125} \mathrm{I}-\mathrm{T} 84.66$ and ${ }^{125} \mathrm{I}-10 \mathrm{H} 6$}

T84.66 and $10 \mathrm{H} 6$ were radiolabeled with ${ }^{125} \mathrm{I}$ with the modified chloramine-T method described previously (Garg and Balthasar, 2007). Briefly, $40 \mu \mathrm{l}$ of antibody ( $1 \mathrm{mg} / \mathrm{ml}$ in $\mathrm{pH}$ 7.4 PBS) was combined with $10 \mu \mathrm{l}$ of $\mathrm{Na}^{125} \mathrm{I}(100 \mathrm{mCi} / \mathrm{ml})$ (PerkinElmer, Waltham, MA) and subsequently reacted with $20 \mu \mathrm{l}$ of chloramine-T $(1 \mathrm{mg} / \mathrm{ml}$ in $\mathrm{pH} 7.4$ PBS). After 90 seconds, the reaction was terminated by the addition of $40 \mu \mathrm{l}$ of $10 \mathrm{mg} / \mathrm{ml}$ potassium iodide. Immediately after the reaction, gel filtration (Sephadex G-25 column; GE Healthcare Bio-Sciences, Pittsburgh, PA) was performed to separate ${ }^{125}$ I-labeled intact antibody from the mixture. A $\gamma$-counter was used (LKB Wallac 1272; Wallac, Turku, Finland) to count the fraction containing 10H6conjugated ${ }^{125} \mathrm{I}$. Thin-layer chromatography (PE SiL-G; Whatman Ltd, Kent, England) was used immediately before pharmacokinetic experiments to confirm that $>99 \%$ of protein was associated with ${ }^{125} \mathrm{I}$.

\section{Evaluation of $10 \mathrm{H} 6$ Cellular Dissociation Kinetics}

We assessed the dissociation kinetics of $10 \mathrm{H} 6$ to $\mathrm{CEA}$ at $\mathrm{pH} 5.0$ and $\mathrm{pH} 7.4$ using a radioligand assay. Approximately $10^{6} \mathrm{LS} 174 \mathrm{~T}$ cells were incubated to equilibrium with $10 \mathrm{nM}$ concentration $10 \mathrm{H} 6$ at $\mathrm{pH}$ 7.4 and 5.0 in PBS/ $1 \%$ BSA for 90 minutes at $4^{\circ} \mathrm{C}$. A concentration of $1 \mathrm{nM}{ }^{125} \mathrm{I}-10 \mathrm{H} 6$ was spiked into each incubation solution to monitor binding of $10 \mathrm{H} 6$ to cells. After incubation, cells were pelleted by centrifugation at $1500 \mathrm{~g}$ for 5 minutes and washed three times with cold $\mathrm{PBS} / 1 \% \mathrm{BSA}, \mathrm{pH}$ 7.4. Kinetic analyses were conducted by resuspending cells in $1 \mu \mathrm{M} 10 \mathrm{H} 6$, pH 7.4 or 5.0. Remaining CEA-bound ${ }^{125} \mathrm{I}-10 \mathrm{H} 6$ was measured over 4 hours at various time points (5-240 minutes). Binding reactions were quenched by centrifuging cells at $14,000 \mathrm{~g}$ for 20 seconds and immediately washing three times with $\mathrm{PBS} / 1 \%$ BSA, $\mathrm{pH}$ 7.4. Samples were then counted for gamma radiation. Monoexponential and biexponential decay equations were used to assess $k_{\text {off }}$ at both $\mathrm{pH}$ levels.

\section{Animals}

Swiss-Webster and C57 BL/6 male mice aged 2 to 3 weeks were purchased from Harlan Laboratories. Athymic nude mice $(\mathrm{Crl}: \mathrm{NU}$ (NCr)-Foxn $1^{\text {nu }}$ ) aged 2 to 3 weeks were purchased from Charles Rivers Laboratories (Charles Rivers Laboratories, Wilmington, MA). Male mice were used because of the ease and reliability of intravenous drug 
administration via the penile vein. Mice were housed in a temperature and humidity-controlled environment with a standard light/dark cycle, where they had access to water and food. All animal protocols complied with the Institutional Animal Care and Use Committee of the State University of New York at Buffalo Animal Facility regulations.

\section{H6 and T84.66 Plasma Pharmacokinetics in Healthy Swiss-Webster Mice}

Two days before dosing, KI ( $0.2 \mathrm{~g} / \mathrm{l})$ was added to the drinking water of all mice to block thyroid uptake of ${ }^{125} \mathrm{I}$. A dose of $1 \mathrm{mg} / \mathrm{kg} 10 \mathrm{H} 6$ or T84.66 with respective $400 \mu \mathrm{Ci}{ }^{125} \mathrm{I}-10 \mathrm{H} 6$ or ${ }^{125} \mathrm{I}-\mathrm{T} 84.66$ tracer doses were administered by penile vein injection to male Swiss-Webster mice ( $n=5$ /group). For each mouse, $20 \mu$ l of blood was serially collected from the retroorbital plexus or the saphenous vein. All samples were centrifuged at $2000 \mathrm{~g}$, and plasma was collected. To remove free and catabolite-associated ${ }^{125} \mathrm{I}$, samples were precipitated by a trichloroacetic acid (TCA) (Sigma Life Sciences) method described earlier (Abuqayyas and Balthasar, 2012b). Briefly, plasma samples $(5 \mu \mathrm{l})$ were added to $200 \mu \mathrm{l}$ of $1 \% \mathrm{v} / \mathrm{v}$ BSA and $10 \% \mathrm{w} / \mathrm{v}$ TCA in PBS and allowed to precipitate on ice for 15 minutes. Precipitated samples were then centrifuged at $14,000 \mathrm{~g}$ for 5 minutes to pellet the precipitate. The supernatant was discarded, and the pellet was then washed three times with PBS. The precipitated samples were then $\gamma$-counted to determine the concentration of anti-CEA mAb in plasma.

\section{Quantification of Shed Plasma CEA in MC38 ${ }^{\text {CEA }}$ Tumor- Bearing C57BL/6 Mice}

Soluble shed plasma CEA was measured in the $\mathrm{MC} 38^{\mathrm{CEA}+}$ tumor mouse model to address the potential impact of soluble plasma antigen on anti-CEA mAb pharmacokinetics. Briefly, MC38 $8^{\mathrm{CEA}+}$ tumors were grown in five male C57BL/6 mice, as described previously. Three mice bearing $\mathrm{MC} 38^{\mathrm{CEA}-}$ tumors were used as negative controls. Terminal plasma samples were collected from each mouse when the tumor size was between 1000 and $2000 \mathrm{~mm}^{3}$ and stored at $-20^{\circ} \mathrm{C}$ until analysis.

Soluble CEA in plasma was measured by a validated ELISA developed previously within the laboratory (Urva et al., 2009). The lower limit of detection for the assay was determined by eq. 2 (Swartz and Krull, 2012):

$$
D L=\frac{3.3 \cdot \sigma}{S},
$$

where $D L$ is the detection limit, $\sigma$ is the S.D. of five blank samples, and $S$ is the slope of the standard curve.

\section{$10 \mathrm{H} 6$ and T84.66 Plasma Pharmacokinetics in a Mouse Model of Colorectal Cancer}

C57BL/6 and athymic nude male mice were injected subcutaneously with ${\mathrm{MC} 38^{\mathrm{CEA}-}}(\mathrm{C} 57 \mathrm{BL} / 6), \mathrm{MC}^{\mathrm{CEA}+}(\mathrm{C} 57 \mathrm{BL} / 6)$, or LS174T (nude mice). Mice were given $\mathrm{KI}(0.2 \mathrm{~g} / \mathrm{l})$ in their drinking water to block nonspecific thyroid uptake of ${ }^{125} \mathrm{I}$. Pharmacokinetic studies were initialized when the tumor size reached $200-300 \mathrm{~mm}^{3}$. Doses of $0.1,1$, and $10 \mathrm{mg} / \mathrm{kg} 10 \mathrm{H} 6$ or T84.66 (MC38 tumor-bearing animals only) with $400 \mu \mathrm{Ci} / \mathrm{kg}$ of ${ }^{125} \mathrm{I}-10 \mathrm{H} 6$ or ${ }^{125} \mathrm{I}-\mathrm{T} 84.66$ were administered intravenously. Blood was serially collected via the retroorbital plexus or saphenous vein. Plasma samples were centrifuged at $2000 \mathrm{~g}$, and plasma was collected. Samples were TCA-precipitated as described previously, and $\gamma$-counted to determine plasma concentration of $10 \mathrm{H} 6$ or T84.66.

\section{Pharmacokinetic Data Analysis}

Pharmacokinetic data were analyzed by standard noncompartmental analysis (NCA) in Phoenix WinNonlin 6.1. Individual parameter estimates were stratified by treatment group, and parameter means and variability were calculated. Statistical significance for pharmacokinetic parameters between treatment groups was determined by Student's two-tailed $t$ test $(P \leq 0.05)$, with the assumption of equal variance (confirmed by F-test). Statistical difference in NCA parameters with dose and tumor target status (CEA+ or CEA-) was determined by two-way analysis of variance (ANOVA) $(P \leq 0.05)$.

\section{Western Blot Confirmation of FcRn Expression}

Protein Extraction. Total protein was extracted from $\mathrm{MC} 38^{\mathrm{CEA}+}$, MC38 ${ }^{\mathrm{CEA}-}$, and LS174T cells using RIPA buffer. Briefly, cells were grown in T-75 flasks until approximately $100 \%$ confluence. Cells were then detached from the flask using Trypsin-EDTA (ThermoFisher, Grand Island, NY) and collected in conical tubes. Cells were then pelleted and washed three times by resuspending in PBS. After washing, a volume of $1 \mathrm{ml}$ RIPA buffer (ThermoFisher) with protease inhibitor (Sigma-Aldrich) was added to the cell pellets and vortexed to suspend the cells. The suspended cells were incubated at $4^{\circ} \mathrm{C}$ with constant agitation for 15 minutes. After the incubation, undissolved cellular debris was pelleted by centrifuging at $14,000 \mathrm{~g}$ for 20 minutes. Supernatant was collected where protein concentration was measured using a Bradford assay (Sigma-Aldrich).

Western Blot. MC38 ${ }^{\mathrm{CEA}+}, \mathrm{MC}^{\mathrm{CEA}-}$, and LS174T cell lysate, along with positive and negative control samples, were prepared in PBS and reducing sample buffer (ThermoFisher). Prepared samples were heated in water bath at $95^{\circ} \mathrm{C}$ for 5 minutes. Heated samples, along with positive and negative control samples, were loaded onto 12\% Precise Tris-HEPES gels (ThermoFisher). Loaded samples were separated at $100 \mathrm{~V}$ for 45 minutes. SDS-PAGE gels were equilibrated in Western blot transfer buffer ( $25 \mathrm{mM}$ Tris-/190 mM glycine buffer with $20 \%$ methanol) for 5 minutes. Polyvinylidene fluoride membranes were briefly soaked in $100 \%$ methanol and then equilibrated in transfer buffer for 5 minutes. Transfer of protein from SDS-PAGE gel to polyvinylidene fluoride membrane was performed at $40 \mathrm{~V}$ for 90 minutes. After transfer, the membranes were blocked in TBST $(0.1 \%$ Tween-20) with $5 \%$ milk for 1 hour at room temperature. After blocking, the membrane was probed with $2 \mu \mathrm{g} / \mathrm{ml}$ of goat anti-mFcRn antibody (R\&D Systems, Inc, Minneapolis, MN) or $5 \mu \mathrm{g} / \mathrm{ml}$ of 7E9 (inhouse mouse anti-hFcRn antibody) in blocking solution overnight at $4^{\circ} \mathrm{C}$. After incubation, the membrane was washed four times with TBST and probed with horseradish peroxidase-conjugated donkey anti-goat IgG antibody at 1:1000 dilution (EMD Millipore, Billerica, MA) or $0.5 \mu \mathrm{g} / \mathrm{ml}$ of horseradish peroxidase-conjugated goat antimouse IgG antibody (Millipore) in blocking solution for 1.5 hours at room temperature. After secondary antibody probing, membranes were washed five times with TBST and incubated in SuperSignal West Pico Chemiluminescent Substrate (Thermo Scientific) for 5 minutes. Finally, membranes were analyzed with the use of a ChemiDOC XRS system (Bio-Rad).

Tumor Pharmacokinetics of Anti-CEA mAbs. We assessed the pharmacokinetics of anti-CEA mAbs $10 \mathrm{H} 6$ and T84.66 in MC38 ${ }^{\mathrm{CEA}+}$ tumors using liquid chromatography-tandem mass spectrometry (LC-MS/MS). MC38 $8^{\mathrm{CEA}+}$ xenograft tumors were established as previously described. Because of limitations in limit of quantification (LOQ)/limit of detection of LC-MS/MS, a $0.5-\mathrm{mg} / \mathrm{kg}$ dose was selected to elucidate the effects of $\mathrm{pH}$-dependent antigen binding on tumor pharmacokinetics. mAbs were administered intravenously via the penile vein. Terminal sacrificing by cardiac puncture $(n=3$ mice per time point) was used to collect blood and tumor samples. Blood samples were centrifuged at $2000 \mathrm{~g}$ for 10 minutes to separate out plasma and stored at $-20^{\circ} \mathrm{C}$. Tumor samples were frozen in liquid $\mathrm{N}_{2}$ immediately after harvest and then stored at $-80^{\circ} \mathrm{C}$ until LC-MS/MS analysis.

\section{LC-MS/MS}

Tissue Sample Processing. Frozen tumors were ground into fine powder in the presence of liquid nitrogen using a 
pestle and mortar. An aliquot of $50.0 \mathrm{mg}$ of tissue powder was suspended in $500 \mu \mathrm{l}$ of lysis buffer ( $50 \mathrm{mM}$ Tris, $150 \mathrm{mM} \mathrm{NaCl}$, $0.5 \%$ sodium deoxycholate, $2 \%$ SDS, $2 \%$ NP-40, $\mathrm{pH}$ was adjusted to 8.0 by formic acid) and homogenized in an ice bath using a Polytron homogenizer (Kinematica, Lucerne, Switzerland). After sonication for 30 seconds, the homogenates were centrifuged at $20,000 \mathrm{~g}$ for 30 minutes at $4^{\circ} \mathrm{C}$, and the supernatants were isolated for digestion. Plasma and tumor samples were prepared using a previously established and validated method (An et al., 2015).

T- $\boldsymbol{\mu L C - M S . ~ A n ~ U l t i M a t e ~} 3000$ LC system (containing SRD3400 degasser, NCS-3500RS CAP pumps and a high-flow tertiary gradient pump, and WPS-3000TBRS autosampler with a 250- $\mu$ l loop) coupled to a TSQ Quantiva triple-quadrupole mass spectrometer (MS) or a Orbitrap Fusion MS (Thermo Fisher Scientific, Santa Clara, CA) was used for selected reaction monitoring (SRM) SRM and high-resolution selected ion monitoring (SIM) SIM analysis, respectively. Sample trapping was conducted on a C8 column $(15 \times 2.1 \mathrm{~mm}, 3.5-\mu \mathrm{m}$ particle size, $100 \AA$; Agilent, Agilent Technologies, Wilmington, DE) at flow rate of $1 \mathrm{ml} / \mathrm{min}$ using the tertiary pump. High-flow loading mobile phase for $A_{\text {trapping }}$ and $B_{\text {trapping }}$ were water:acetonitrile of $98: 2$ and $5: 95(\mathrm{v} / \mathrm{v})$ containing $1 \mathrm{mM}$ ammonium formate $(\mathrm{pH}=9.0$, adjusted by ammonium hydroxide). A microflow selector (5-50 $\mu \mathrm{l} / \mathrm{min}$ ) was used for $\mu \mathrm{LC}-\mathrm{MS}$. The separation column was a Zorbax C18 stable bond column $(150 \times 0.5 \mathrm{~mm}, 3.5 \mu \mathrm{m}$, $100 \AA$; Agilent) at a flow rate of $25 \mu \mathrm{l} / \mathrm{min}$. Low-flow MP $A_{\text {analysis }}$ and $B_{\text {analysis }}$ for $\mu \mathrm{LC}$ were water:acetonitrile:formic acid of 98:2:0.1 and 5:95:0.1 (v/v/v, pH = 3.0). After MCX SPE enrichment, $10 \mu \mathrm{l}$ of sample was loaded for analysis. The separation temperature was controlled at $40^{\circ} \mathrm{C}$. The Spray voltage was $3.5 \mathrm{kV}$, vaporizer temperature was $50^{\circ} \mathrm{C}$, Sheath gas was 15.0 Arb, Aux gas was 2.0 Arb, and the capillary temperature was maintained at $325^{\circ} \mathrm{C}$. Isolation window was set to $0.2 \mathrm{Th}$ for $\mathrm{Q} 1$, and $0.7 \mathrm{Th}$ for $\mathrm{Q} 3$ on the triple-quadrupole MS for SRM analysis (T84.66). Resolution of 500,000 was used on Orbitrap Fusion for highresolution SIM analysis (10H6, CEA). Experimentally selected signature peptides were quantified for the targets: 1) 10H6: SGAGSLVHSDGNTYLEWYLQKPGQSPK and SLEWLGYLSCYNQTSYNQK and 2) T84.66: ASNLESGIPVR and QRPEQGLEWIGR.

Calibration and Validation. Standard proteins were spiked into pooled blank matrices to prepare calibration curves. The standard calibrator samples were diluted with blank matrix to a range of concentrations. Hybrid calibration strategy was used in this study as specified previously (NouriNigjeh et al., 2014). SIL-peptide I.S. was spiked after digestion of the calibration samples. Calibration curves were established by plotting extracted ion current peak area ratio of the analyte/I.S. as a function of analyte concentration. For the quantification of the target proteins in biologic samples, weighted least-squares linear regression analysis of the standard curves was used. For validation, a batch of quality control (QC) samples were prepared containing low, medium, and high concentrations of target protein in biomatrices, and this sample set was compared with independently prepared calibration standards. Precision of the assay was calculated by repeated analysis of spiked QC samples, and CV\% of the replicate measurements was calculated to determine variability. Quantitative accuracies of the $\mathrm{QC}$ samples at each concentration level were calculated against nominated concentrations.

\section{Results}

Anti-CEA mAb Development and Characterization. The mouse producing the highest signal from the antigen capture ELISA was selected for fusion. After a period of 10 days, hybridoma colonies were readily visible in $\sim 75 \%$ of the wells. The process of identifying anti-CEA IgG pooled cell culture media (eight wells/pool) and subsequently testing the individual wells of pooled media that returned ELISA signals of greater than three times baseline led to the identification of seven anti-CEA IgG producing hybridoma cell lines (data not shown). The method of single-cell picks was performed in two successive cycles to produce monoclonal hybridoma cell lines.

To test for $\mathrm{pH}$-dependent target binding, the antigen capture ELISA was applied to filtered cell culture media containing anti-CEA antibodies (Fig. 1A). Except for 10H6, the panel of anti-CEA antibodies did not exhibit a dramatic decrease in ELISA signal with acidification of media. For $10 \mathrm{H} 6$, the assay signal at $\mathrm{pH} 5.5$ was $5 \%$ of the signal observed at $\mathrm{pH}$ 7.0. To confirm that the $\mathrm{pH}$-dependent binding phenomenon was reversible within this assay, a portion of acidified media was adjusted to $\mathrm{pH} 7.0$, and the assay was repeated (Fig. 1B). No statistically significant difference was found between $\mathrm{pH} 7.0$ media, and media incubated at $\mathrm{pH} 5.5$ that was neutralized ( $P=0.15$, Student's two tailed $t$ test). With characterization at more $\mathrm{pH}$ values, we found a monotonic decline in signal with $\mathrm{pH}$, where the assay response was decreased by $\sim 50 \%$ at 6.0 and by $\sim 90 \%$ at pH 5.0 (Fig. 1C).

Further characterization of $\mathrm{pH}$-dependent properties of antiCEA mAbs was completed using a competitive ELISA. Binding of CEA by anti-CEA mAb was competed with by the respective $\mathrm{AP}-\mathrm{mAb}$ conjugate. Owing to sensitivity issues at low $\mathrm{pH}$, binding of anti-CEA mAbs was evaluated at $\mathrm{pH} 7.4$ and $\mathrm{pH}$ 6.0. For $10 \mathrm{H} 6$, model fitting of data with an inhibition function resulted in an equilibrium dissociation constant at $\mathrm{pH} 7.4$ of $12.57 \pm 1.682$ and $144.6 \pm 21.79 \mathrm{nM}$ at $\mathrm{pH}$ 6.0. For T84.66, equilibrium dissociation constants at $\mathrm{pH} 7.4$ and 6.0 were $1.095 \pm 0.1103$ and $1.363 \pm$ $0.1584 \mathrm{nM}$, respectively (Fig. 2). A pH-dependent difference was found between the equilibrium dissociation constant for $10 \mathrm{H} 6$ ( $P=$ $0.0005)$, but not for T84.66 $(P=0.074)$. Between group statistical analysis, evaluated with one-way ANOVA, determined statistical significance between $10 \mathrm{H} 6$ and T84.66 at pH $6.0(P<0.0001)$ and no statistical difference at $\mathrm{pH} 7.4(P=0.7336)$. The resulting $K_{\mathrm{D}}$ ratio between $\mathrm{pH} 6.0$ and 7.4 for $10 \mathrm{H} 6$ is 11.5. This ratio is consistent with previously constructed $\mathrm{pH}$-dependent antibodies in literature (Igawa et al., 2010; Chaparro-Riggers et al., 2012).

Results from flow cytometry experiments indicated that $10 \mathrm{H} 6$ binds cellular CEA in a solvent accessible region in two cell lines (Fig. 3). Experiments with MC38 ${ }^{\mathrm{CEA}-}$ cells (isotype control, secondary antibody only, positive control T84.66, and 10H6) show no visual shift in the mean fluorescence intensity (MFI) histogram and no substantial change in the geometric mean of the MFI. The CEA-expressing cell lines MC38 ${ }^{\mathrm{CEA}+}$ and LS174T both exhibited a near baseline shift in MFI for T84.66 and $10 \mathrm{H} 6$ relative to controls. For MC38 ${ }^{\mathrm{CEA}+}$, there was a 13.3- and 19.6-fold increase in MFI geometric mean relative to isotype control for T84.66 and 10H6. In LS174T cells, there was a measured 123- and 243-fold increase in geometric mean for T84.66 and 10H6, respectively. 
A

B

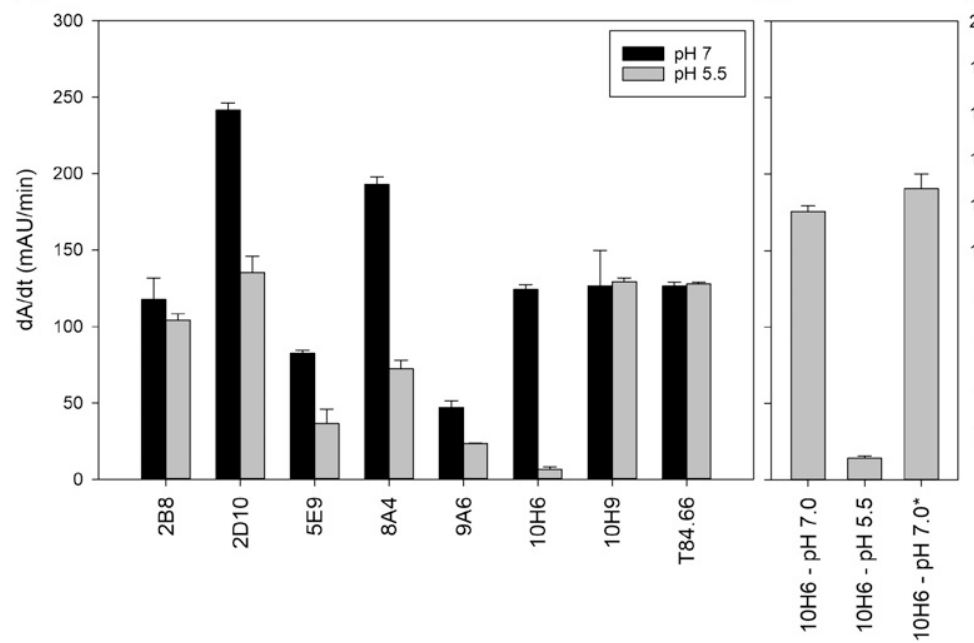

C

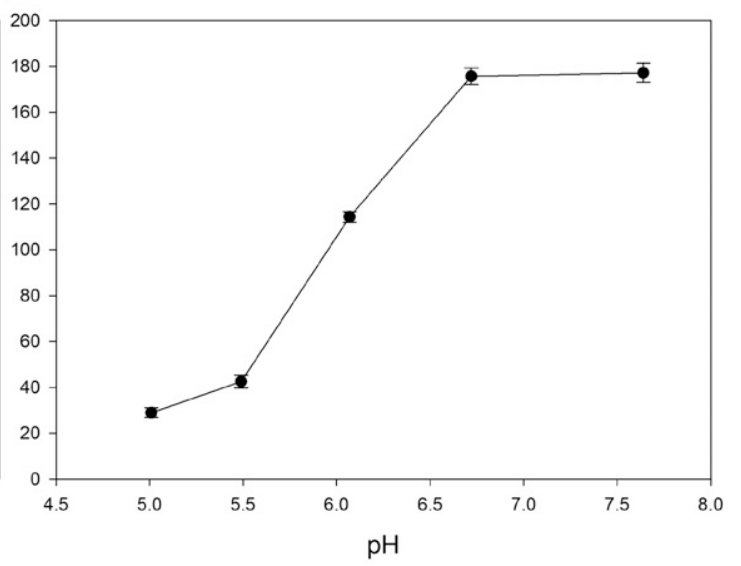

Fig. 1. Analysis of pH-dependent binding of anti-CEA antibodies by using an antigen capture ELISA. (A) Assay response (dA/dt) at pH 7.0 and $\mathrm{pH} 5.5$ for a panel of anti-CEA antibodies. $10 \mathrm{H} 6$ shows a dramatic reduction in equilibrium binding at $\mathrm{pH} 5.5$ relative to $\mathrm{pH} 7.0$. (B) Reversibility of binding within this assay was demonstrated by assaying $\mathrm{pH} 5.510 \mathrm{H} 6$ media that was neutralized back to $\mathrm{pH} 7.0(10 \mathrm{H} 6, \mathrm{pH} 7.0 *)$. Assay measurements of $\mathrm{pH} 7.010 \mathrm{H} 6$ and neutralized pH 7.0 media suggested no statistical difference in signal. (C) $10 \mathrm{H} 6$ anti-CEA antibody tested over a range of pH demonstrated $\mathrm{pH}$-sensitive binding. Data points represent the mean of three ELISA measurements; error bars denote the standard deviation of the mean.

Cellular binding constants were elucidated using a radioligand binding assay with LS174T cells at physiologic and acidic $\mathrm{pH}$. Radiolabled $10 \mathrm{H} 6$ was spiked into solution containing unlabeled concentrations of $10 \mathrm{H} 6$ and $\sim 10^{6}$ LS174T cells. After incubation to equilibrium at $\mathrm{pH} 7.4$, kinetic dissociation rate constants $\left(k_{\text {off }}\right)$ were evaluated by resuspending LS174T cells in $\mathrm{pH} 7.4$ or 5.0 buffer containing $1.0 \mu \mathrm{M}$ unlabeled 10H6. Bound ${ }^{125} \mathrm{I}-10 \mathrm{H} 6$ was measured over time after resuspension. Values for $k_{\text {off }}$ were determined by fitting decay equations to percent bound over time data. The $k_{\text {off }}$ values at $\mathrm{pH} 7.4$ and $\mathrm{pH} 5.0$ were $0.01331 \pm$ 0.001909 minute $^{-1}$ and $0.8729 \pm 0.1970$ minute $^{-1}$, respectively (Fig. 4). As shown in Fig. 4, nearly $100 \%$ of $10 \mathrm{H} 6$ dissociated from the membrane of LS174T cells after 5 -minute incubation in $\mathrm{pH} 5.0$ buffer. The observed $k_{\text {off }}$ values correspond to dissociation half-lives of 60.1 and 0.79 minutes at $\mathrm{pH} 7.4$ and 5.0, respectively.
Pharmacokinetics of T84.66 and $10 \mathrm{H6}$ in SwissWebster Mice. To assess the suitability of T84.66 as an IgG1 $\kappa$ control in pharmacokinetic studies, the plasma pharmacokinetics of T84.66 and $10 \mathrm{H} 6$ were measured in male Swiss-Webster mice after a single $1-\mathrm{mg} / \mathrm{kg}$ dose. The plasma pharmacokinetics of T84.66 and $10 \mathrm{H} 6$ are shown in Fig. 5. Both mAbs exhibit biexponential pharmacokinetics, with a clearance of $8-8.5 \mathrm{ml} /$ day per kilogram (Table 1 ). No statistical difference (Student's unpaired $t$ test) was seen in the mean plasma clearance $(P=0.62)$; however, the $10 \mathrm{H} 6$ calculated mean volume of distribution at steady state $\left(V_{\mathrm{ss}}\right)$ was significantly greater than the mean $V_{\mathrm{ss}}$ found for T84.66 $(P=0.042)$.

Pharmacokinetics of T84.66 and $10 \mathrm{H6}$ in MC38 ${ }^{\mathrm{CEA}+}$ and MC38 ${ }^{\text {CEA- }}$ Tumor-Bearing C57BL/6 Mice. The plasma pharmacokinetics of anti-CEA mAbs $10 \mathrm{H} 6$ and T84.66 were assessed in male $\mathrm{C} 57 \mathrm{BL} / 6$ mice bearing $\mathrm{MC}^{2} 8^{\mathrm{CEA}+}$ and

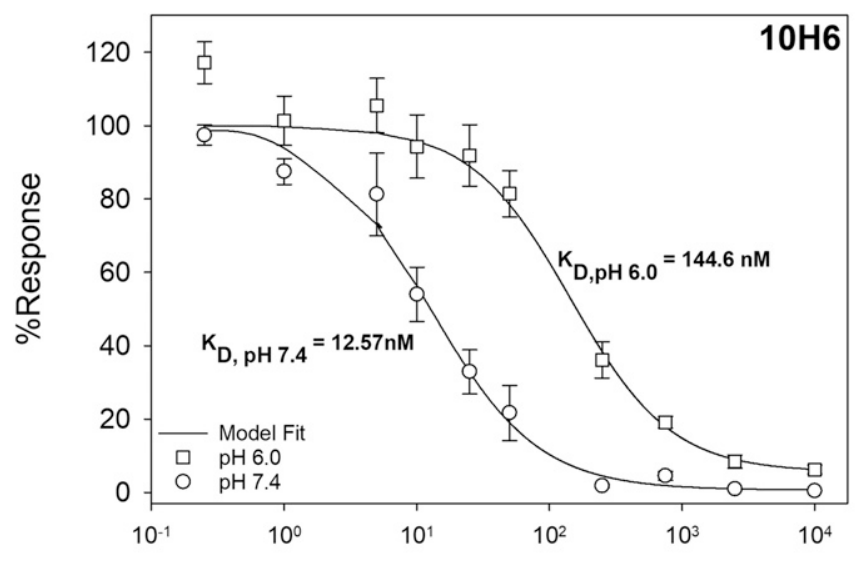

[Unlabeled Antibody] (nM)

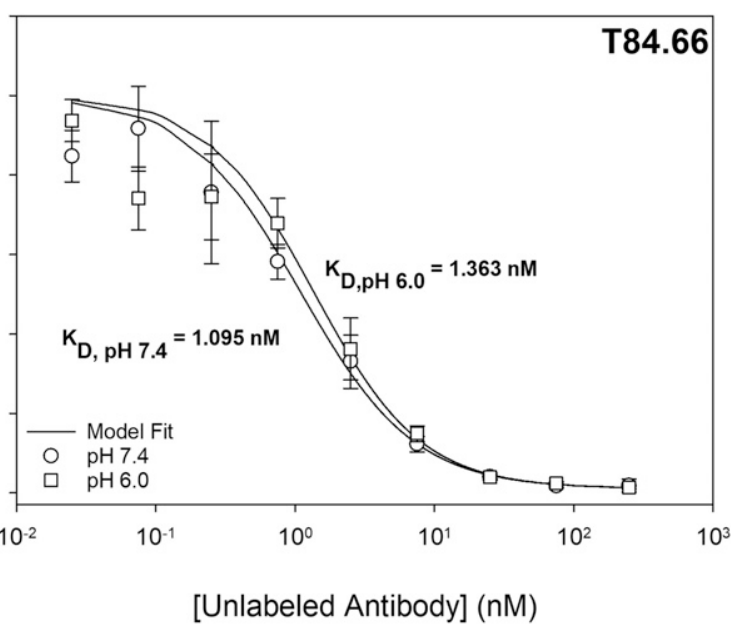

[Unlabeled Antibody] (nM)

Fig. 2. Analysis of pH-dependent binding of anti-CEA antibodies by using competitive ELISA. The left panel displays responses of unlabeled 10H6 competing with AP-conjugated $10 \mathrm{H} 6$ at $\mathrm{pH} 7.4$ and 6.0. The right panel displays the responses for T84.66 at both described pH levels. Data were fit using an inhibition model to determine equilibrium binding dissociation constants. 


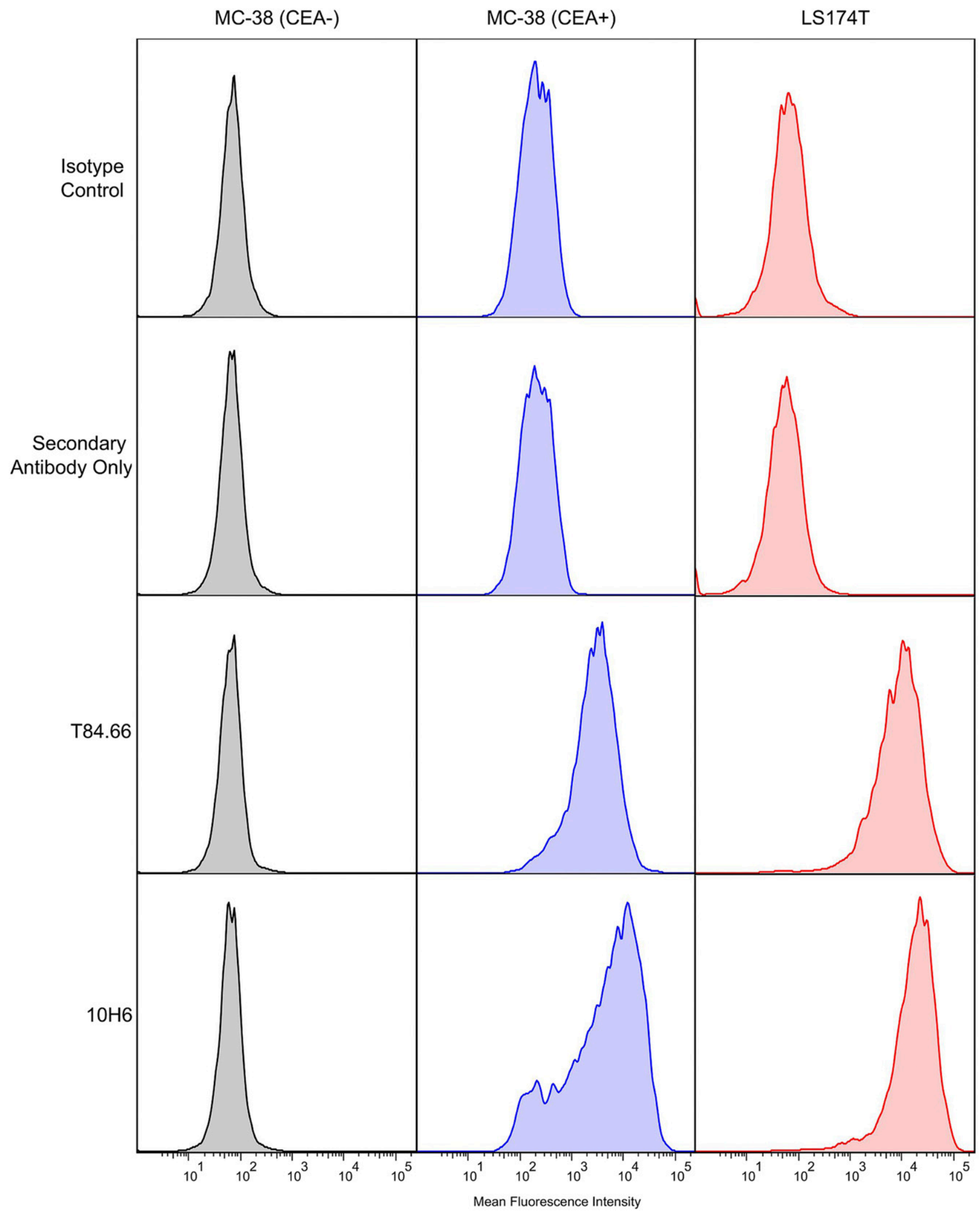

Fig. 3. Measurement of T84.66 and $10 \mathrm{H} 6$ binding to MC38 ${ }^{\mathrm{CEA}-}$ (gray), MC38 ${ }^{\mathrm{CEA}+}$ (blue), and LS174T (red) by flow cytometry. MC38 ${ }^{\mathrm{CEA}-}$ has no detectable shift in the distribution of mean fluorescence intensity for either T84.66 or 10H6 compared with controls, indicating no detectable binding of the anti-CEA antibodies to the antigen-free cell line. The CEA-expressing cell lines MC38 ${ }^{\mathrm{CEA}+}$ and LS174T both show large shift in the distribution to higher mean fluorescence intensity relative to controls, indicating specific binding of antibody to antigen in the cell-based system. 


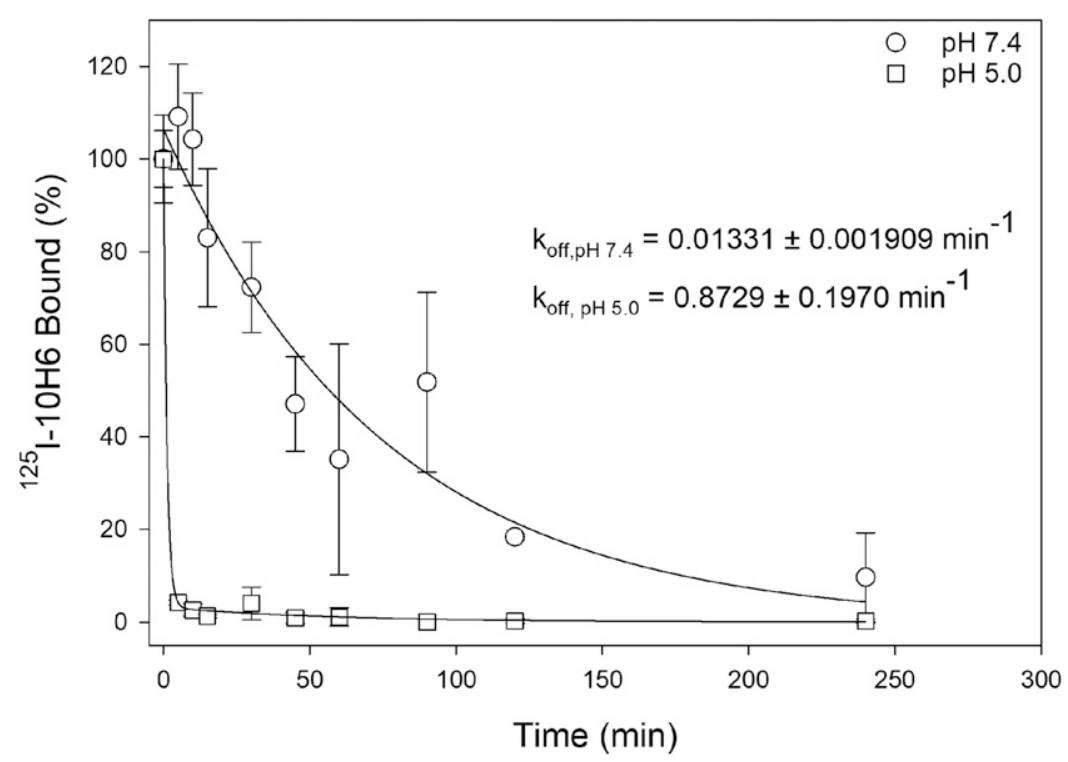

Fig. 4. Evaluation of $10 \mathrm{H} 6$ dissociation kinetics from membrane-bound CEA on LS174T cells at physiologic $\mathrm{pH}$ (7.4, circles) and endosomal $\mathrm{pH}$ (5.0, squares). Data were fit using monoexponential and biexponential decay kinetics for $\mathrm{pH} 7.4$ and 5.0 data, respectively. The dissociation rate constant $\left(k_{\mathrm{off}}\right)$ for $\mathrm{pH} 5.0$ is expressed as the $\alpha$-phase rate.
MC38 ${ }^{\mathrm{CEA}-}$ tumors after i.v. bolus doses of $0.1,1$, or $10 \mathrm{mg} / \mathrm{kg}$. Fig. 6, A and B, shows the plasma pharmacokinetic profiles for T84.66 and $10 \mathrm{H} 6$ in tumor-bearing mice, with dosenormalized data shown in Fig. 6, C and D. T84.66 and $10 \mathrm{H} 6$ display biexponential pharmacokinetics in $\mathrm{MC} 38^{\mathrm{CEA}-}$ tumor-bearing mice. Two-way ANOVA grouped by anti-CEA $\mathrm{mAb}$ and dose provides no evidence of statistical differences in plasma clearance or $V_{\mathrm{SS}}$ in the MC38 ${ }^{\mathrm{CEA}-}$ mouse model (Fig. 7). In MC38 ${ }^{\mathrm{CEA}+}$ mice, all dose levels of $10 \mathrm{H} 6$ visually overlay the corresponding dose in MC38 ${ }^{\mathrm{CEA}-}$ control mice, with similar biexponential pharmacokinetics. In contrast, the data for T84.66 show clear dose-dependencies in pharmacokinetics in mice bearing MC38 ${ }^{\mathrm{CEA}+}$ tumors. Inspection of the dose-normalized T84.66 data (Fig. 6C) shows a decreased terminal half-life for the 0.1 and $1 \mathrm{mg} / \mathrm{kg}$ doses in mice with MC38 $8^{\mathrm{CEA}+}$ tumors and a decreased relative exposure compared with dose-matched MC38 ${ }^{\mathrm{CEA}-}$ controls. The pharmacokinetic parameters for each group were estimated by noncompartmental analysis (Table 1). No statistical difference was found by two-way ANOVA in $10 \mathrm{H} 6$ plasma clearance or $V_{\mathrm{SS}}$ in $\mathrm{MC} 8^{\mathrm{CEA}+}$ or $\mathrm{MC} 38^{\mathrm{CEA}-}$ tumor bearing mice, at each dose level, suggesting that the presence of target (i.e., CEA) does not substantially affect the pharmacokinetics for this anti-CEA CAR $\mathrm{mAb}$ (Fig. 7, B and D). Conversely, statistical analysis of T84.66 plasma pharmacokinetics revealed significant differences for plasma clearance and $\mathrm{V}_{\mathrm{SS}}$ for comparisons by tumor type and by dose (two-way ANOVA, $P \leq 0.05$ ) (Fig. 7, A and C). Although the $1 \mathrm{mg} / \mathrm{kg}$ T84.66 dose in MC38 ${ }^{\mathrm{CEA}+}$ mice shows a terminal half-life that is 2-fold less than the dose-matched control (in MC38 ${ }^{\mathrm{CEA}-}$ mice), and there appears to be visual evidence of a trend toward nonlinear pharmacokinetics (Fig. 6C), the plasma clearance was not statistically different between the two groups (Student's t test, $P=0.095)$. At the lowest dose level $(0.1 \mathrm{mg} / \mathrm{kg})$, T84.66 pharmacokinetics exhibited clear nonlinearity in MC38 ${ }^{\mathrm{CEA}+}$-bearing mice (Fig. 6C). Statistical comparisons for $\mathrm{T} 84.66$ at the $0.1 \mathrm{mg} / \mathrm{kg}$ dose in $\mathrm{MC} 38^{\mathrm{CEA}-}$ and $\mathrm{MC} 38^{\mathrm{CEA}+}$ mice

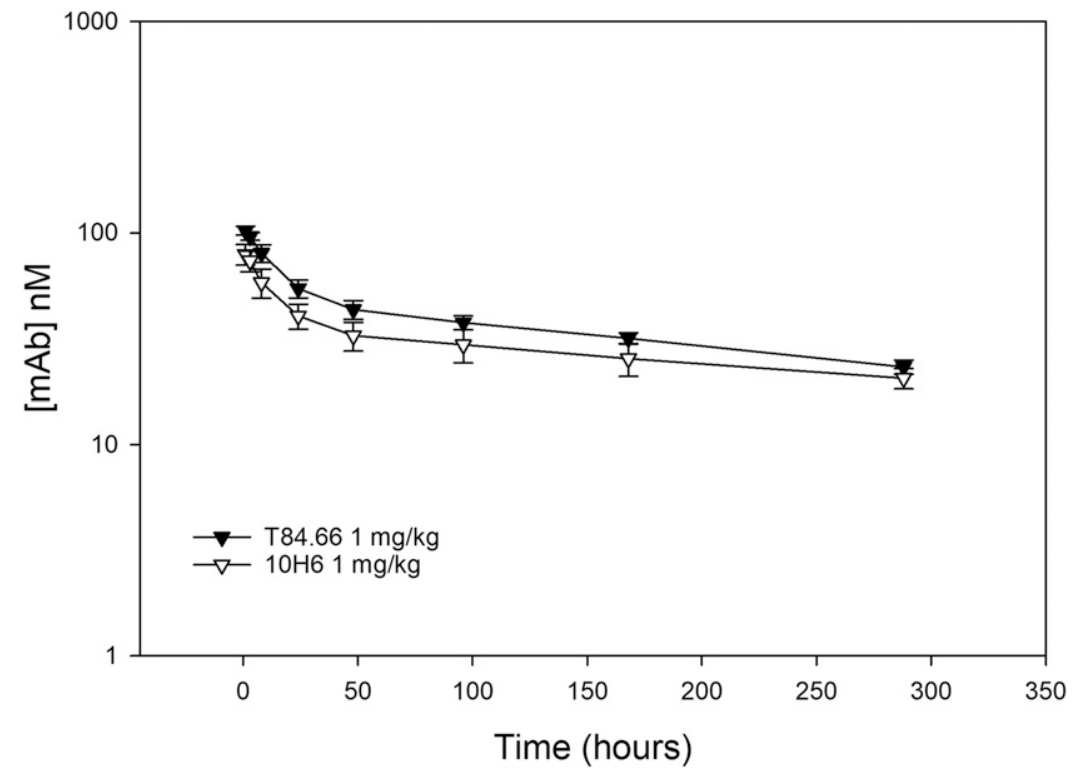

Fig. 5. Pharmacokinetics of T84.66 and $10 \mathrm{H} 6$ after an i.v. $1 \mathrm{mg} / \mathrm{kg}$ dose in healthy male Swiss-Webster mice. Data points represent the mean plasma concentration $(n=4$ to 5 ), and error bars denote the standard deviation of the mean. 
TABLE 1

Noncompartmental analysis (NCA)-derived pharmacokinetic parameters for T84.66 or 10H6 after an intravenous dose in mouse models

$V_{\mathrm{SS}}$ is NCA-determined volume of distribution at steady state. It is recognized that this value is not appropriately determined at dose-levels associated with non-linear pharmacokinetics. CL refers to the time-averaged systemic clearance, determined as dose/AUC.

\begin{tabular}{|c|c|c|c|c|c|}
\hline \multirow{2}{*}{$\begin{array}{l}\text { Monoclonal } \\
\text { Antibody }\end{array}$} & \multirow{2}{*}{ Tumor } & \multirow{2}{*}{ Dose } & \multicolumn{3}{|c|}{ NCA Parameter Estimates ${ }^{a}$} \\
\hline & & & $V_{\mathrm{ss}}$ & Clearance & Terminal $t_{1 / 2}$ \\
\hline T84.66 & - & $m g / k g 1$ & $\begin{array}{c}\mathrm{ml} / \mathrm{kg} \\
127 \pm 11\end{array}$ & $\begin{array}{c}\text { ml/day per kilogram } \\
8.06 \pm 0.60\end{array}$ & $\begin{array}{c}d a y \\
11.5 \pm 1.3\end{array}$ \\
\hline $10 \mathrm{H} 6$ & - & 1 & $180 \pm 35$ & $8.40 \pm 0.97$ & $15.6 \pm 4.1$ \\
\hline $\mathrm{T} 84.66$ & $\mathrm{MC} 38^{\mathrm{CEA}-}$ & 0.1 & $93.9 \pm 9.0$ & $14.4 \pm 2.8$ & $4.87 \pm 2.6$ \\
\hline $\mathrm{T} 84.66$ & MC38 ${ }^{\text {CEA- }}$ & 1 & $97.0 \pm 12$ & $11.9 \pm 1.1$ & $6.00 \pm 0.63$ \\
\hline T84.66 & MC38 $8^{\mathrm{CEA}-}$ & 10 & $93.7 \pm 5.5$ & $13.8 \pm 1.5$ & $5.09 \pm 0.57$ \\
\hline T84.66 & $\mathrm{MC} 38^{\mathrm{CEA}+}$ & 0.1 & $65.5 \pm 6.6$ & $24.6 \pm 5.7$ & $1.30 \pm 1.0$ \\
\hline T84.66 & MC38 $8^{\mathrm{CEA}+}$ & 1 & $75.3 \pm 6.1$ & $24.3 \pm 1.3$ & $2.97 \pm 1.0$ \\
\hline T84.66 & MC38 $8^{\mathrm{CEA}+}$ & 10 & $95.5 \pm 11$ & $10.8 \pm 2.6$ & $7.12 \pm 2.5$ \\
\hline $10 \mathrm{H} 6$ & MC38 ${ }^{\mathrm{CEA}-}$ & 0.1 & $93.6 \pm 8.7$ & $15.3 \pm 1.8$ & $4.38 \pm 0.52$ \\
\hline $10 \mathrm{H} 6$ & MC38 ${ }^{\mathrm{CEA}-}$ & 1 & $103 \pm 30$ & $12.7 \pm 2.8$ & $6.26 \pm 2.5$ \\
\hline $10 \mathrm{H} 6$ & MC38 ${ }^{\mathrm{CEA}-}$ & 10 & $80.9 \pm 7.1$ & $14.9 \pm 4.9$ & $4.30 \pm 0.97$ \\
\hline $10 \mathrm{H} 6$ & $\mathrm{MC} 38^{\mathrm{CEA}+}$ & 0.1 & $81.2 \pm 10$ & $16.2 \pm 2.4$ & $3.64 \pm 1.0$ \\
\hline $10 \mathrm{H} 6$ & MC38 $8^{\mathrm{CEA}+}$ & 1 & $88.3 \pm 19$ & $13.7 \pm 1.8$ & $5.17 \pm 1.6$ \\
\hline $10 \mathrm{H} 6$ & $\mathrm{MC} 38^{\mathrm{CEA}+}$ & 10 & $94.4 \pm 12$ & $10.1 \pm 1.7$ & $7.00 \pm 1.0$ \\
\hline $10 \mathrm{H} 6$ & $\mathrm{LS} 174 \mathrm{~T}^{b}$ & 0.1 & $205 \pm 64$ & $229 \pm 88$ & $1.16 \pm 0.35$ \\
\hline $10 \mathrm{H} 6$ & $\mathrm{LS} 174 \mathrm{~T}$ & 1 & $227 \pm 76$ & $39.9 \pm 14.8$ & $4.60 \pm 1.59$ \\
\hline $10 \mathrm{H} 6$ & LS174T & 10 & $113 \pm 49$ & $27.2 \pm 10.5$ & $3.22 \pm 0.71$ \\
\hline
\end{tabular}

${ }^{a}$ Parameter estimates are presented as mean \pm S.D.

${ }^{b}$ Parameter estimates were evaluated from data greater than LOQ (1-72 h)

*NCA assumes all elimination occurs from the plasma compartment. Elimination from the tissue space (i.e., target mediated elimination) is likely to lead to an under prediction of $V_{\mathrm{ss}}$.

demonstrated significant differences for plasma clearance $(P=$ $0.012)$ and $V_{\mathrm{SS}}(P=0.001)$, indicating that the presence of target influences the pharmacokinetics of T84.66 at this dose (Fig. 7, A and $\mathrm{C}$ ).

To assess the possibility of shed soluble CEA in plasma in mice bearing large $\mathrm{MC} 38^{\mathrm{CEA}+}$ tumors, terminal plasma samples were taken from tumor-bearing mice, where soluble CEA concentrations were quantified via ELISA. All samples tested in either control or tumor-bearing mice exhibited plasma CEA concentrations below the calculated lower limit of detection $(3.8 \mathrm{ng} / \mathrm{ml}$ or $0.021 \mathrm{nM})$.

Pharmacokinetics of $10 \mathrm{H6}$ in LS174T Xenograft Athymic Nude Mice. To assess the influence of FcRn on 10H6 pharmacokinetics, a human-derived tumor cell line (LS174T) that expresses hCEA, but lacks expression of mFcRn, was used to establish a xenograft tumor model. $10 \mathrm{H} 6$ plasma concentrations were analyzed in athymic nude mice bearing LS174T tumors after an i.v. dose of $0.1,1.0$, and $10 \mathrm{mg} / \mathrm{kg}$. Figure 8A shows the plasma concentration-time profiles for $10 \mathrm{H} 6$ in LS174T tumor-bearing mice, with dosenormalized data shown in Fig. 8B. $10 \mathrm{H} 6$ terminal phases of 1.0 and $10 \mathrm{mg} / \mathrm{kg}$ exhibited apparent similarity, but the $0.1 \mathrm{mg} / \mathrm{kg}$ dose demonstrated a rapid increase in the terminal-phase slope, indicating an increased elimination rate. Upon dose normalization of plasma concentrations, there is a clear discrepancy between the $0.1 \mathrm{mg} / \mathrm{kg}$ dose group and the two higher doses, consistent with target-mediated elimination. Pharmacokinetic parameters were calculated using noncompartmental analysis. Plasma clearances at each dose were assessed based on the pharmacokinetic equation $\mathrm{CL}=$

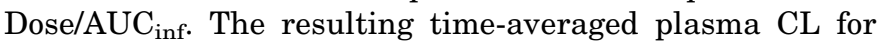
10H6 in athymic nude mice bearing LS174T tumors at 0.1-, $1.0-$, and $10-\mathrm{mg} / \mathrm{kg}$ doses are displayed in Table 1. Statistical analysis determined no significant difference between 1.0 and $10 \mathrm{mg} / \mathrm{kg}(P=0.298)$. In contrast, the plasma clearance of the $0.1 \mathrm{mg} / \mathrm{kg}$ dose group was statistically significant from 1 to $10 \mathrm{mg} / \mathrm{kg}$ dose groups $(P=0.004$ and $P=0.003)$. These results are consistent with target-mediated elimination of antibody.

Tumor Pharmacokinetics of Anti-CEA mAbs. Comparing $10 \mathrm{H} 6$ plasma clearances with the $\mathrm{pH}$-independent antibody, T84.66, in the presence of CEA and $\mathrm{mFcRn}$ in MC38 ${ }^{\mathrm{CEA}+}$ tumors, $10 \mathrm{H} 6$ and T84.66 have statistically different plasma clearances at low doses $(0.1 \mathrm{mg} / \mathrm{kg}, P=0.016)$, where target-mediated effects are most prominent. By minimizing target-mediated elimination, we hypothesized that 10H6 would exhibit greater tumor exposure (as well as increased plasma exposure). To examine this hypothesis, tumor pharmacokinetics of the two anti-CEA mAbs, with and without CAR properties, were evaluated in C57BL/6 male mice bearing MC38 $8^{\mathrm{CEA}+}$ tumors, with analysis via LC-MS/MS. Plasma concentration versus time profiles for T84.66 and 10H6 (Fig. 9A) were consistent with prior work, where T84.66 exhibits a greater terminal-phase slope than $10 \mathrm{H} 6$ in $\mathrm{MC} 38^{\mathrm{CEA}+}$ tumor-bearing mice. The plasma $\mathrm{AUC}_{0-\mathrm{t}}$ values for T84.66 and $10 \mathrm{H} 6$ were $69.32 \pm 7.810$ and $166.4 \pm$ $6.685 \mathrm{nM} \cdot$ day, respectively. Estimates for plasma CL were obtained from the equation Dose/AUC $\mathrm{An}_{\mathrm{t}}$. Clearance values were calculated as $48.09 \pm 5.42$ and $20.04 \pm 0.81 \mathrm{ml} /$ day per kilogram for T84.66 and 10H6. Applying the modified BailerSatterthwaite method (Nedelman et al., 1995), confidence intervals for AUC determined a significant difference, $P<$ 0.05. Plasma CL was also deemed significantly different after statistical analysis using propagation of error method (Motulsky, 1995). These data suggest that $10 \mathrm{H} 6$ exhibits a greater plasma exposure than T84.66 in an MC38 ${ }^{\mathrm{CEA}+}$ xenograft mouse model owing to the slower clearance from systemic circulation. 
A
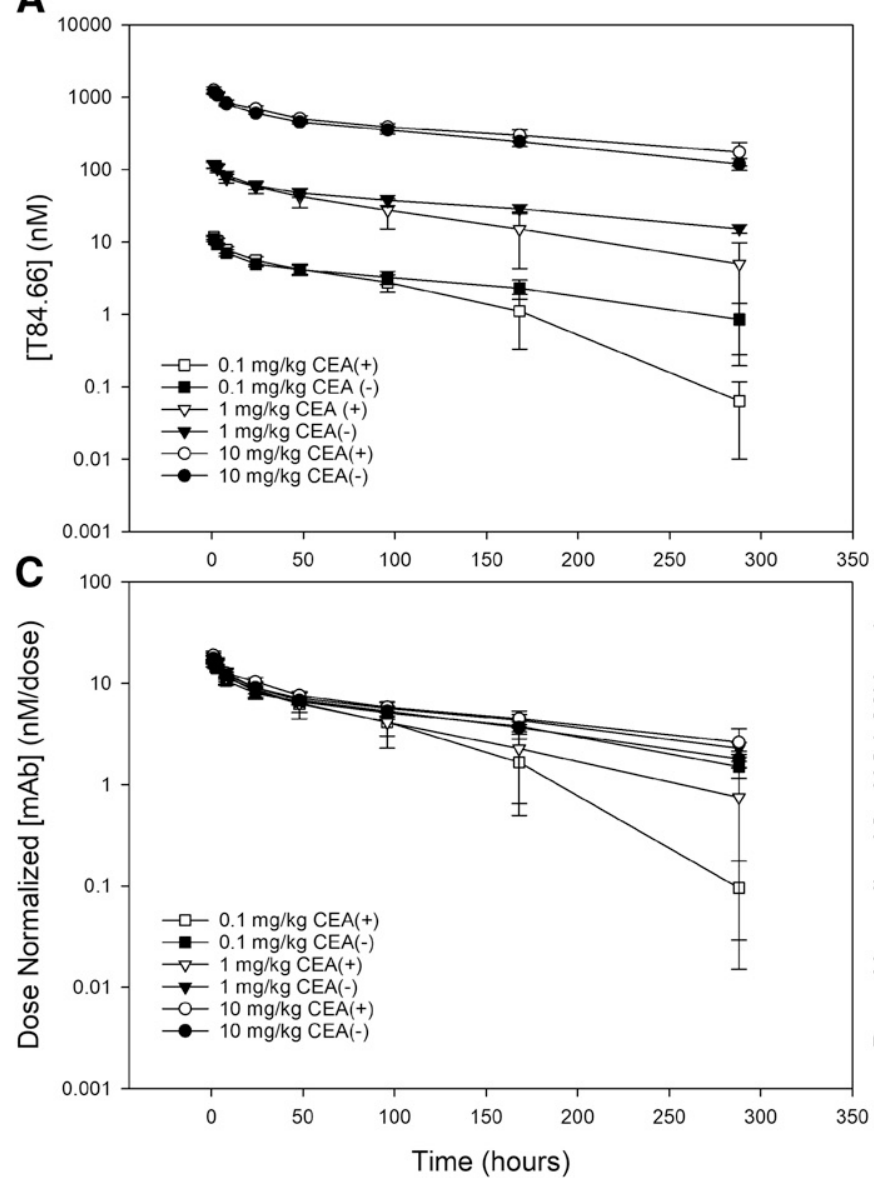

B
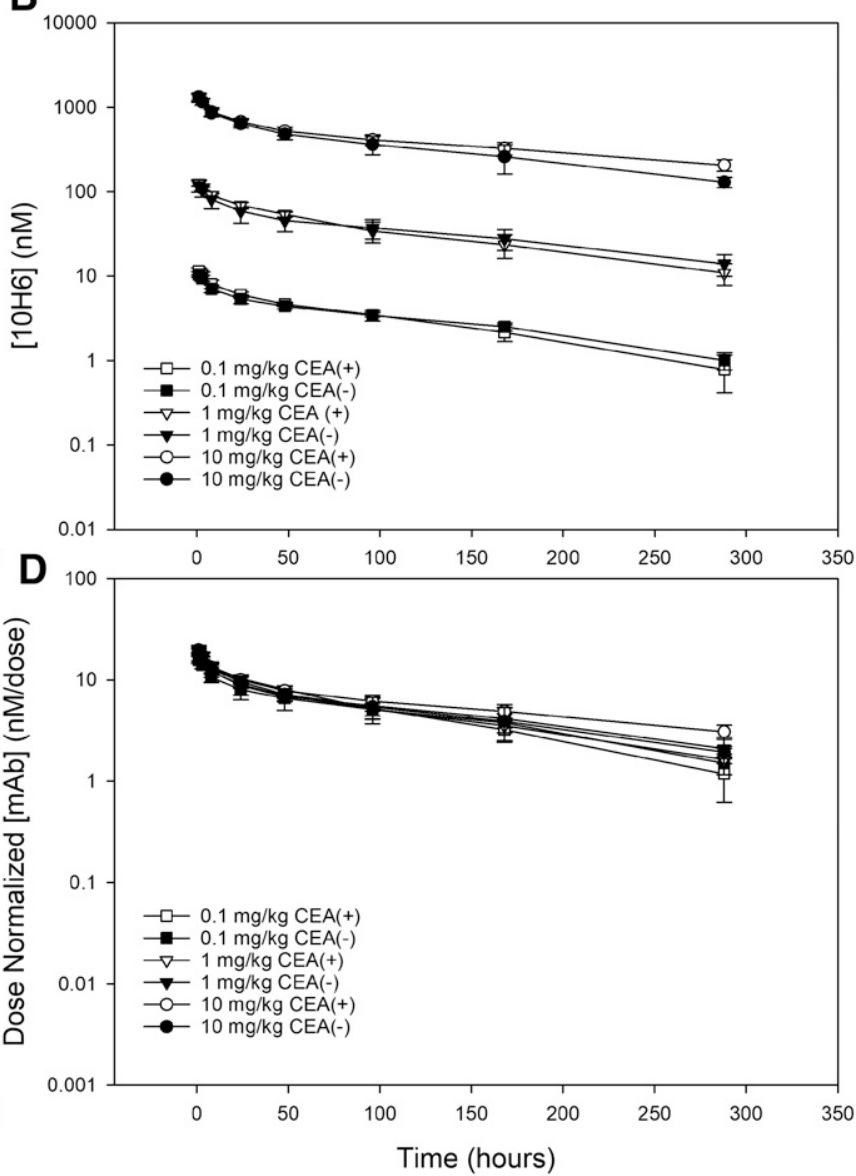

Fig. 6. Pharmacokinetics of (A) T84.66 and (B) $10 \mathrm{H} 6$ after an i.v. 0.1 (square), 1 (triangle), or $10 \mathrm{mg} / \mathrm{kg}$ (circle) dose in C57 BL/6 male mice bearing MC38 ${ }^{\mathrm{CEA}-}$ (closed symbols) or MC38 ${ }^{\mathrm{CEA}+}$ (open symbols) tumors. Dose normalization of (C) T84.66 and (D) $10 \mathrm{H} 6$ data suggests an increased elimination rate for T84.66 at 0.1 and $1 \mathrm{mg} / \mathrm{kg}$ doses in CEA-bearing mice. Data points represent the mean plasma concentration $(n=4$ to 5$)$, and error bars denote the standard deviation of the mean.

$\mathrm{MC} 38^{\mathrm{CEA}+}$ tumor concentration-time profiles of T84.66 and $10 \mathrm{H} 6$ are shown in Fig. 9B. Data analysis was carried out using the same methods as for the plasma pharmacokinetics. Tumor tissue $\mathrm{AUC}_{0-\mathrm{t}}$ for $\mathrm{T} 84.66$ was $75.69 \pm 5.060$ and 98.35 $\pm 6.510 \mathrm{nM} \cdot$ day for $10 \mathrm{H} 6$. Comparison of T84.66 and $10 \mathrm{H} 6$ tumor AUC, through application of the modified BailerSatterthwaite method, showed that $10 \mathrm{H} 6$ tumor exposure was statistically different from (i.e., greater than) T84.66 tumor exposure $(P<0.05)$, supporting the hypothesis that $\mathrm{CAR} \mathrm{pH}$-dependent binding improves tumor exposure for antiCEA mAb.

Western Blot Confirmation of FcRn Expression. A previously validated Western blot for mouse and human FcRn was used to identify the expression of $\mathrm{FcRn}$ within tumor cell lines used in these studies. Detection of $\mathrm{mFcRn}$ in MC38 tumor cells was accomplished using a commercialized anti$\mathrm{mFcRn}$ antibody. The commercial antibody was successful in identifying recombinant $\mathrm{FcRn}(\mathrm{MW}=35 \mathrm{kDa})$ as well as FcRn expressed within liver tissue samples of male Swiss-Webster mice (Fig. 10A). No hFcRn was detected from recombinant expressed product or from $\mathrm{hFcRn}$ transgenic mice liver tissue samples using this antibody (data not shown). MC $38^{\mathrm{CEA}+}$ cell lysates were probed with anti-mFcRn revealed a band at approximately $53 \mathrm{kDa}$ (Fig. 10A, Lane 4), whereas a band at this molecular weight was absent in MC $38^{\mathrm{CEA}-}$ cell lysate.
This band was consistent with $\mathrm{mFcRn}$ expressed within wildtype mouse liver tissue samples, indicating MC3 ${ }^{\mathrm{CEA}+}$ tumor cells express $\mathrm{mFcRn}$. Detection of $\mathrm{hFcRn}$ in LS174T cells was accomplished using an in-house anti-hFcRn antibody, 7E9. This antibody was successful in identifying positive controls of recombinant $\mathrm{hFcRn}$ and $\mathrm{hFcRn}$ from transgenic mice liver tissue (Fig. 10B). LS174T cell lysate was probed with 7E9 revealed a band at approximately $47 \mathrm{kDa}$, consistent with $\mathrm{hFcRn}$ molecular weight. These data demonstrate that MC38 cells express $\mathrm{mFcRn}$, but not $\mathrm{hFcRn}$, and that LS174T cells express $\mathrm{hFcRn}$, but not $\mathrm{mFcRn}$ (as expected based on their species of origin).

\section{Discussion}

CAR mAbs are a promising new subclass of antibody drugs that have been shown to exhibit decreased target-mediated elimination relative to "standard" $\mathrm{mAbs}$ (where target binding is relatively stable within the $\mathrm{pH}$ range of 5.5-7.4). This study details the development and evaluation of the first reported $\mathrm{CAR} \mathrm{mAb}(10 \mathrm{H} 6)$ with affinity for a cancer-associated antigen. We found that $10 \mathrm{H} 6$ exhibits linear pharmacokinetics in a mouse tumor model of colorectal cancer, whereas a standard anti-CEA mAb (T84.66) demonstrates dose-dependent, nonlinear pharmacokinetics in the same animal model. 

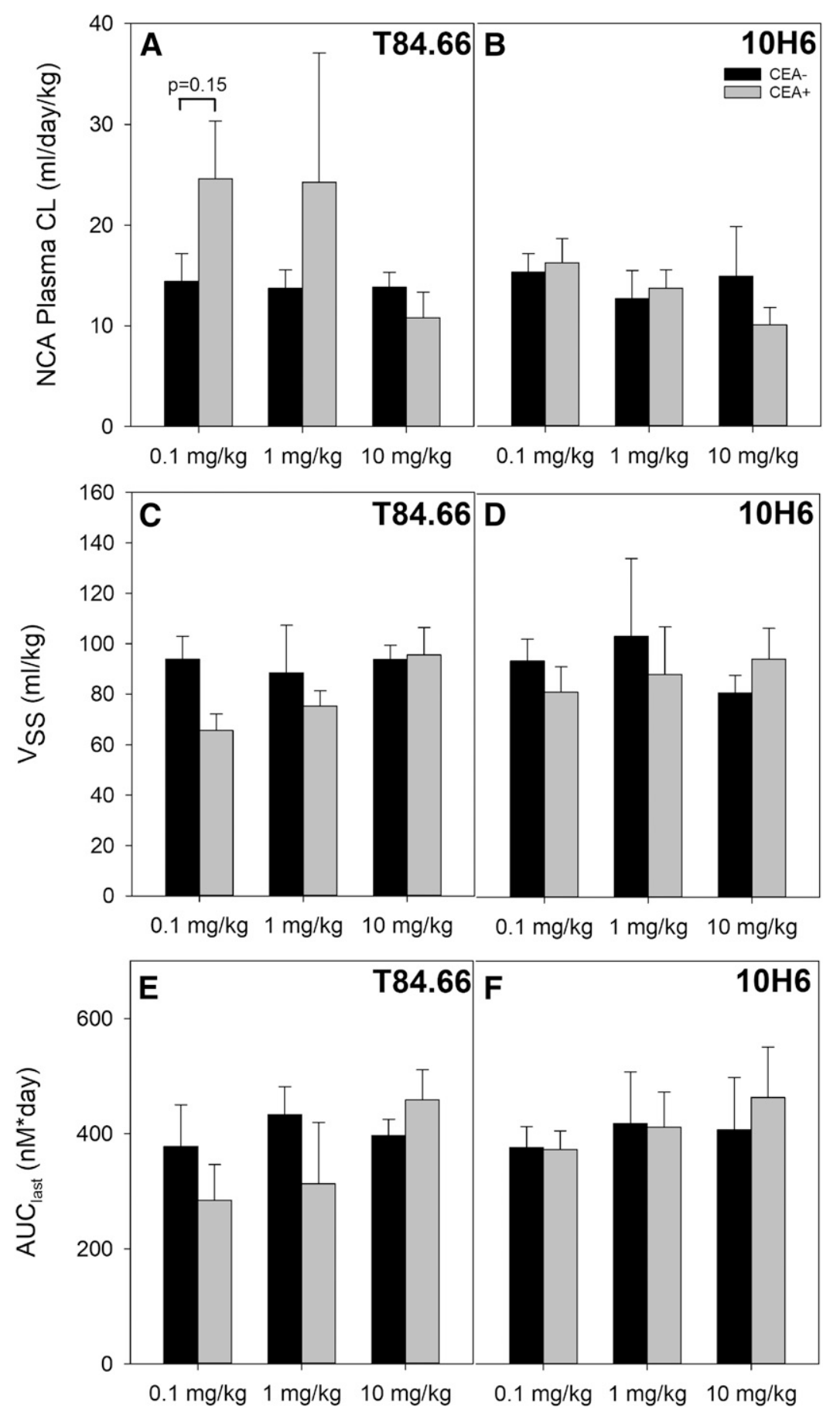

Fig. 7. NCA-derived plasma clearance (CL), steady-state volume of distribution $\left(V_{\mathrm{SS}}\right)$, and dose-normalized exposure $\left(\mathrm{AUC}_{\text {last }}\right)$ in mice dosed with $0.1,1$, or $10 \mathrm{mg} / \mathrm{kg}$ of T84.66 (black bars) or 10H6 (gray bars). (A) T84.66 plasma CL was significantly increased $(P \leq 0.05$, Student's unpaired $t$ test) in mice with $\mathrm{CEA}+$ tumors, relative to control at the $0.1 \mathrm{mg} / \mathrm{kg}$ dose level. (B) $10 \mathrm{H} 6$ plasma CL was not significantly different in the dose range tested. (C) T84.66 $V_{\mathrm{SS}}$ increased significantly in mice with CEA+ tumors relative to control. (D) $10 \mathrm{H} 6 V_{\mathrm{SS}}$ had no significant difference in the dose range tested. $\mathrm{AUC}_{\text {last }}$ was not statistically different any of the measured doses for (E) T84.66 or (F) 10H6. Bars represent the parameter mean ( $n=4$ to 5 ), and error bars denote the standard deviation of the mean.
A Swiss-Webster mouse model, absent of target, was used for initial assessment of the pharmacokinetics of T84.66 and 10H6. Although the CAR mAb (10H6) and control standard binding $\mathrm{mAb}$ (T84.66) are of the same isotype (IgG1 $\kappa$ ), additional factors may influence the rate of $\mathrm{mAb}$ catabolism in a target free system. For example, FcRn binding (Wani et al., 2006; Datta-Mannan et al., 2007; Yeung et al., 2009), glycosylation (Goetze et al., 2011), immunogenicity (KuusReichel et al., 1994), and charge (Boswell et al., 2010; Schoch et al., 2015) have all been demonstrated to contribute to the pharmacokinetics of mAbs in target-free systems. Here, we found no significant differences in the plasma clearance of
$10 \mathrm{H} 6$ and T84.66 in healthy male mice. Further, in MC38 ${ }^{\mathrm{CEA}-}$ tumor-bearing mice, which also lack expression of CEA, there was no significant difference in the plasma clearance of $10 \mathrm{H} 6$ and T84.66.

To evaluate properly the pharmacokinetic benefits of CAR binding to CEA, it was necessary to select a model with expression of the target on cells that are capable of FcRnmediated mAb binding and transport. 10H6, a murine IgG1 $\mathrm{mAb}$, is not expected to bind to human FcRn (Ober et al., 2001). As such, commonly used human tumor lines that express CEAs (e.g., LS174T, HT29) were not suitable to evaluate the beneficial effect of CAR mAbs. Consequently, 
A

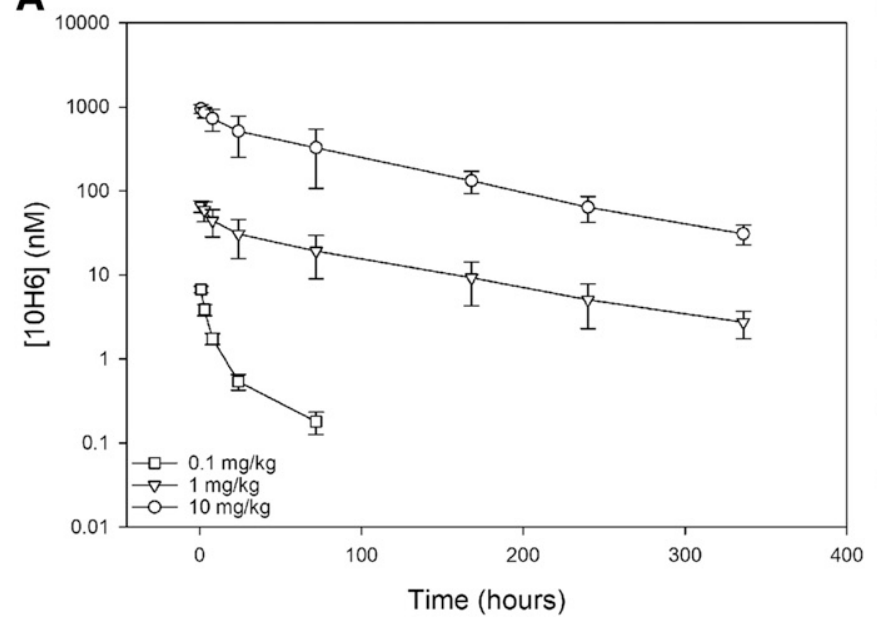

B

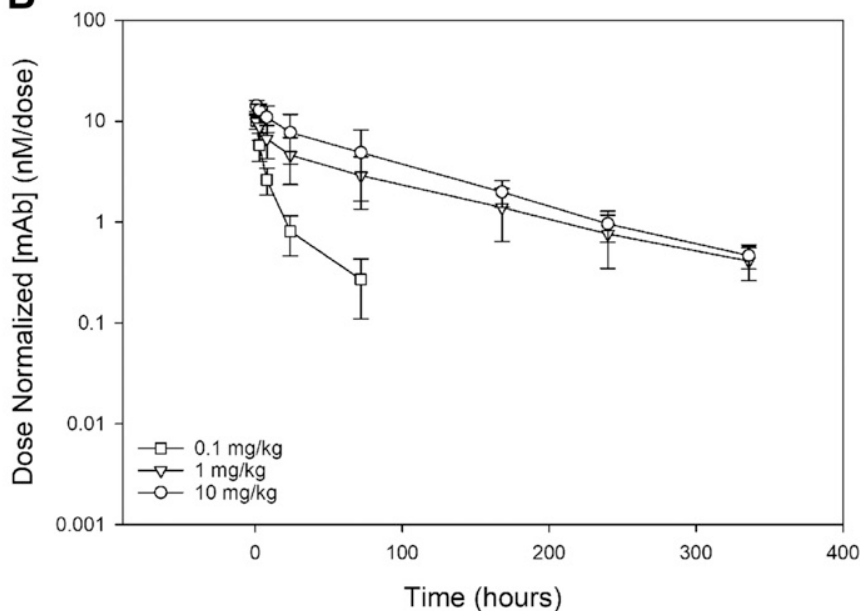

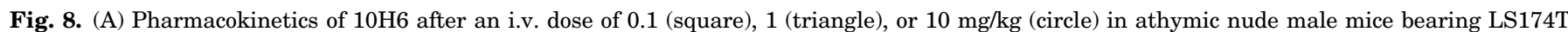

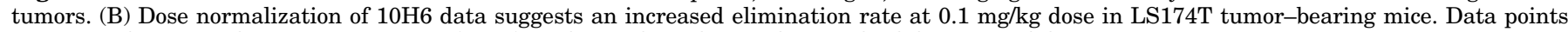
represent the mean plasma concentration $(n=3)$, and error bars denote the standard deviation of the mean.

we selected the $\mathrm{MC} 38^{\mathrm{CEA}+}$ cell line for use in our initial investigations; this cell line is of murine origin and expresses murine FcRn with affinity for murine IgG (including T84.66 and $10 \mathrm{H} 6$ ) based on Western blot analysis. MC38 ${ }^{\mathrm{CEA}+}$ cells have been transfected to express our target of interest (human CEA), and internalization of anti-CEA mAbs by the MC38 ${ }^{\mathrm{CEA}+}$ cell line has been previously verified (Orava et al., 2010). The expression level of CEA in MC $38^{\mathrm{CEA}+}$ tumors has been estimated at $\sim 50 \mathrm{nM}$ (Robbins et al., 1991).

T84.66, which binds to CEA with similar activity at $\mathrm{pH} 5.5$ and at $\mathrm{pH}$ 7.4. (Fig. 1A and Fig. 2), has been shown in prior work to exhibit nonlinear, target-mediated disposition in mouse xenograft models (Urva and Balthasar, 2010; Urva et al., 2010; Abuqayyas and Balthasar, 2012a). In athymic male mice bearing LS174T xenografts, T84.66 dosed at 1, 10, and $25 \mathrm{mg} / \mathrm{kg}$ shows a dose-dependent decrease in plasma clearance and an increase in dose-normalized exposure with increasing dose (Urva and Balthasar, 2010; Abuqayyas and
Balthasar, 2012a). In mice with HT29 xenografts, we studied T84.66 plasma pharmacokinetics at doses ranging from 0.025 to $25 \mathrm{mg} / \mathrm{kg}$. Again, nonlinear pharmacokinetics were observed, with rapid clearance at 0.025 and $0.1 \mathrm{mg} / \mathrm{kg}$, and with slower elimination and dose-proportional pharmacokinetics over the dose range of $1-25 \mathrm{mg} / \mathrm{kg}$ (Abuqayyas and Balthasar, 2012a). The observation of nonlinear pharmacokinetics at higher dose levels in the LS174T mouse model may be explained, in part, by CEA target expression. The LS174T cell line has a 10- and 20-fold greater measured CEA protein expression than HT29 and MC $38^{\mathrm{CEA}+}$ cells (Shi et al., 1983). Other factors that play a role in the extent of target-mediated elimination include antigen-mAb turnover rate, leakiness of the tumor vasculature, and tumor blood flow rates. Here, we evaluated the effect of $\mathrm{FcRn}$ recycling on the pharmacokinetics of anti-CEA mAbs. As demonstrated using Western blot, mice bearing $\mathrm{MC} 38^{\mathrm{CEA}+}$ tumors express $\mathrm{mFcRn}$, resulting in linear pharmacokinetics of $10 \mathrm{H} 6$ and nonlinear pharmacokinetics of
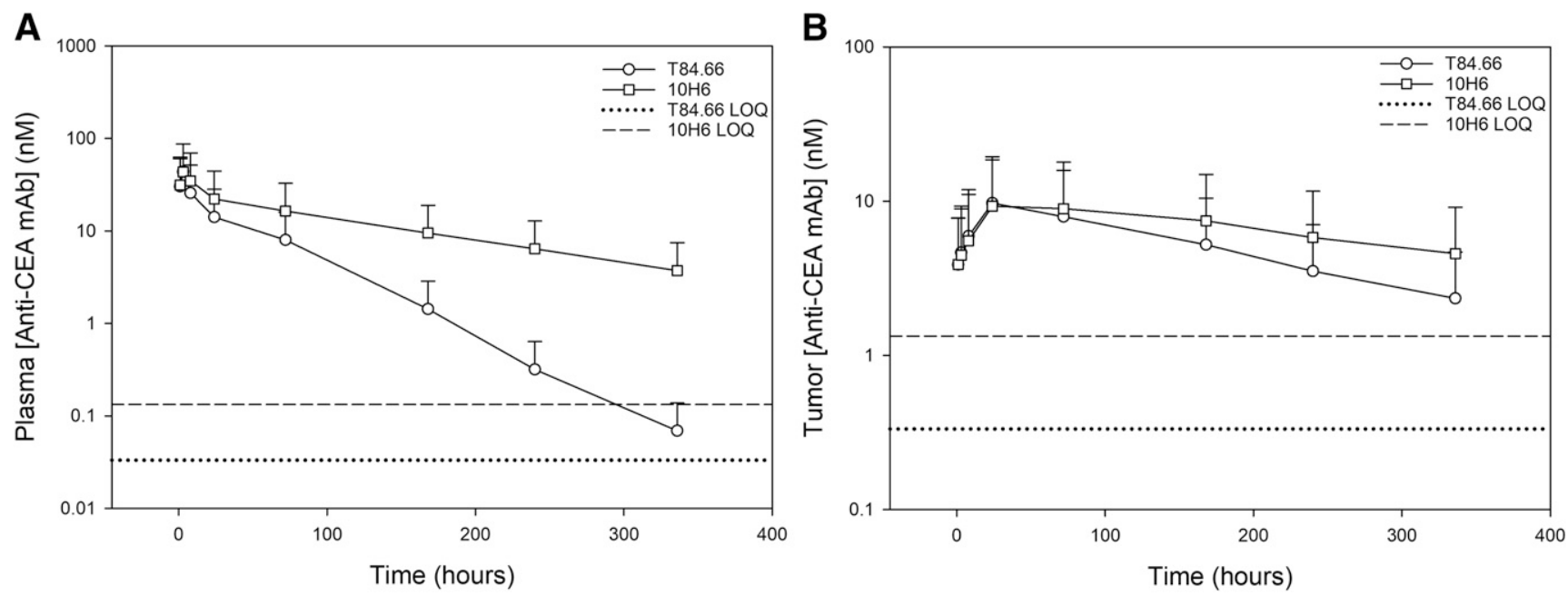

Fig. 9. (A) Plasma and (B) MC38 $8^{\mathrm{CEA}+}$ tumor pharmacokinetics of T84.66 (O) and 10H6 ( $\square$ ) after a 0.5-mg/kg i.v. dose. Horizontal lines represent lower limits of quantification of the LC-MS/MS method. For plasma, LOQs for $10 \mathrm{H} 6$ and T84.66 were $0.02(0.13 \mathrm{nM})$ and $0.005 \mu \mathrm{g} / \mathrm{ml}(0.033 \mathrm{nM})$. For tumor, LOQs for $10 \mathrm{H} 6$ and T84.66 were $0.2(1.3 \mathrm{nM})$ and $0.05 \mu \mathrm{g} / \mathrm{ml}(0.33 \mathrm{nM})$. 

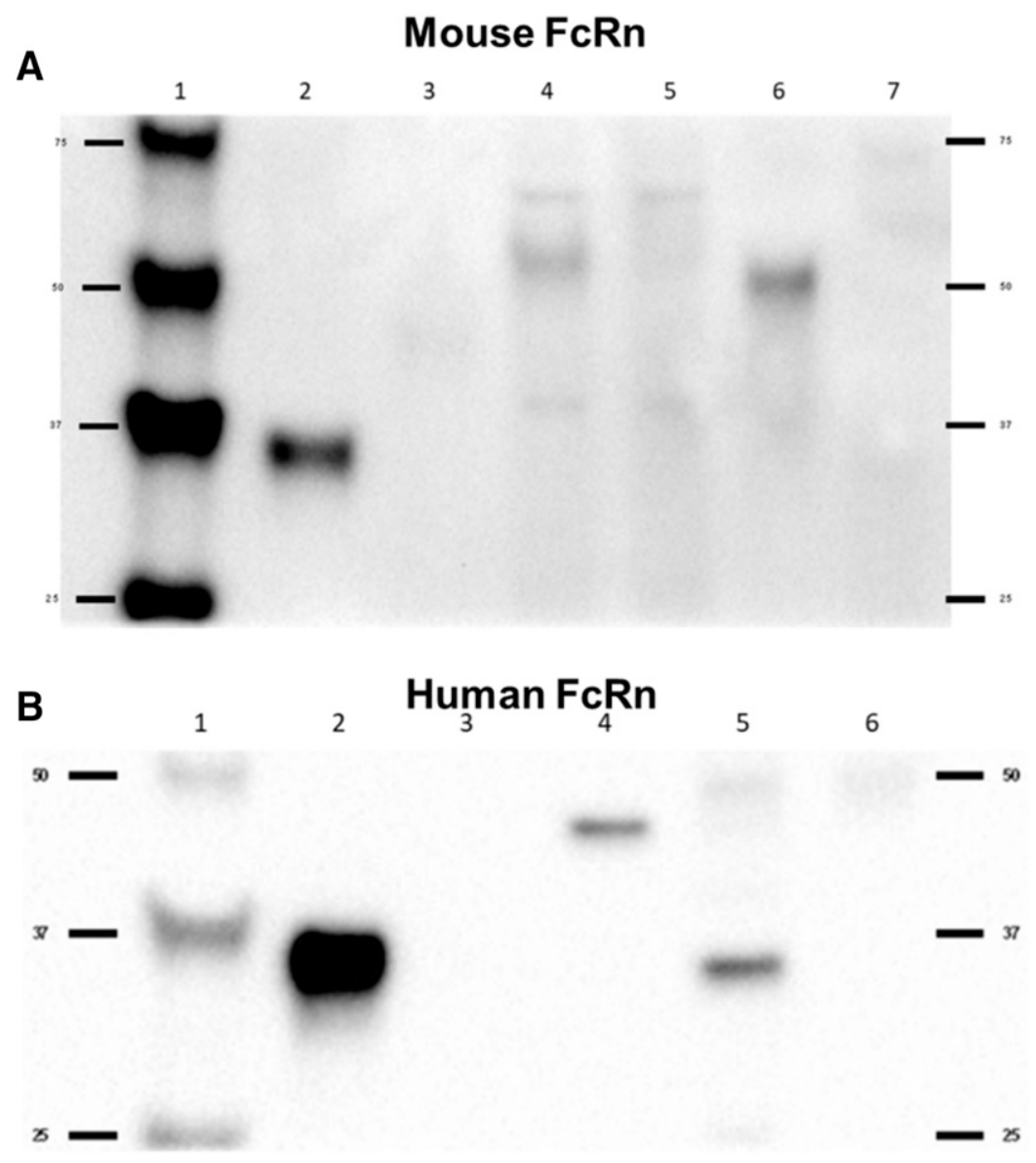

56
Fig. 10. Western blot analysis for (A) $\mathrm{mFcRn}$ and (B) hFcRn in tumor cell lines. (A) Lane 1: Molecular weight ladder. Lane 2: Positive control (23 fmol of recombinant $\mathrm{mFcRn}$ protein). Lane 3: Negative control (220 fmol recombinant $\mathrm{hFcRn}$ protein). Lane 4: $20 \mu \mathrm{g}$ of extracted protein from MC38 ${ }^{\mathrm{CEA}+}$ cells. Lane 5: $20 \mu \mathrm{g}$ of extracted protein from MC38 ${ }^{\mathrm{CEA}-}$ cells. Lane 6: Positive control (2.5 $\mu \mathrm{g}$ of extracted protein from Swiss-Webster mouse liver tissue). Lane 7: Negative control (18 $\mu \mathrm{g}$ of extracted protein from $\mathrm{hFcRn}$ transgenic mouse liver tissue). (B) Lane 1: Molecular weight ladder. Lane 2: Positive control (220 fmol recombinant $\mathrm{hFcRn}$ protein). Lane 3: Negative control (23 fmol of recombinant $\mathrm{mFcRn}$ protein). Lane 4: $5 \mu \mathrm{g}$ of extracted protein from LS174T cells. Lane 5: Positive control $(18 \mu \mathrm{g}$ of extracted protein from $\mathrm{hFcRn}$ transgenic mouse liver tissue). Lane 6: Negative control (2.5 $\mu \mathrm{g}$ of extracted protein from Swiss-Webster mouse liver tissue).
T84.66. On the other hand, in a mouse model system where tumors lack expression of mFcRn (e.g., LS174T tumors), both antibodies would be expected to exhibit target-mediated elimination. As shown in this and prior work in our laboratory, $10 \mathrm{H} 6$ and T84.66 both demonstrate target-mediated elimination in mice bearing LS174T tumors, presumably owing to the internalization of mAb-CEA complexes and the lack of $\mathrm{mFcRn}$-mediated rescue from intracellular catabolism. These studies, combined with our cellular binding assays, support our hypothesis that linear pharmacokinetics observed within MC38 ${ }^{\mathrm{CEA}+}$ mice can be attributed to $\mathrm{pH}$-dependent release of CEA by $10 \mathrm{H} 6$, association with $\mathrm{mFcRn}$, and recycling out of the cell.

Shed antigen in plasma has often been associated with increased $\mathrm{mAb}$ elimination and decreased $\mathrm{mAb}$ exposure. For example, $64 \%$ of patients with HER2 + breast cancer exhibited elevated levels of antigen (extracellular domain of HER2) in plasma (Treish et al., 2000). These patients were more likely to have decreased trough concentrations of trastuzumab relative to patients with no detectable shed antigen in plasma (Treish et al., 2000). CEA is well recognized as a shed antigen, and plasma CEA concentrations are used clinically as a diagnostic marker (Goldstein and Mitchell, 2005). Recognizing that shed CEA may be an important contributing factor in the plasma pharmacokinetics of anti-CEA mAbs, the determination of shed antigen concentration in model animal systems is of interest. In previous work with the LS174T xenograft mouse model, with mice bearing tumors up to $\sim 2000 \mathrm{~mm}^{3}$, the plasma concentrations of CEA were below the limit of quantification $(<2 \mathrm{ng} / \mathrm{ml})$ (Urva et al., 2009). Consistent with these findings, none of the $\mathrm{C} 57 \mathrm{BL} / 6$ mice bearing subcutaneous $\mathrm{MC} 38^{\mathrm{CEA}+}$ tumors $\left(1000-2000 \mathrm{~mm}^{3}\right.$ ) had detectable ( $>3.8 \mathrm{ng} / \mathrm{ml}$ ) levels of soluble plasma CEA (data not shown). The lower limit of detection of CEA in our assay was more than 3 -fold lower than the lowest (molar) mean concentration measured for either T84.66 or 10H6, suggesting that soluble CEA was unlikely to have a substantial effect on the plasma pharmacokinetics of anti-CEA mAbs in this study. In human colorectal cancer, plasma concentrations of CEA increase with disease progression (i.e., increasing from an average of $<1 \mathrm{ng} / \mathrm{ml}$ in Duke stage A disease to an average of $72 \mathrm{ng} / \mathrm{ml}$ [ 1 nM] in Duke stage D disease (Wanebo et al., 1978; Bombski et al., 2002)). In comparison, based on expectations for typical mAb pharmacokinetics in humans, the plasma concentrations of an anti-CEA CAR mAb, after an i.v. dose of $0.1 \mathrm{mg} / \mathrm{kg}$, may be expected to exceed $15 \mathrm{nM}$ for $>2$ weeks. Considering the relative concentrations of antibody and soluble antigen, it is unlikely that soluble CEA would be an important determinant of the pharmacokinetics of CAR antiCEA mAb in most cancer patients. Nonetheless, the effects of soluble CEA on the pharmacokinetics of anti-CEA CAR mAb in patients may merit future clinical evaluation.

In contrast to the standard binding $\mathrm{mAb} \mathrm{T} 84.66$, this work demonstrates no significant differences, as a function of dose, in NCA-derived pharmacokinetic parameters for $10 \mathrm{H} 6$ in mice bearing $\mathrm{MC} 38^{\mathrm{CEA}-}$ or $\mathrm{MC} 38^{\mathrm{CEA}+}$ tumors. Previously, CAR mAbs directed against PCSK9 (Chaparro-Riggers et al., 2012) or IL-6R (Igawa et al., 2010) demonstrated reduced 
target-mediated elimination (relative to their respective "standard binding" parent antibodies). Unlike the highly accessible PCSK9 and IL-6R antigens, the cancer-associated membrane target CEA is found within the relatively inaccessible interstitium of solid tumors. To access target, the CAR $\mathrm{mAb}$ must extravasate the tumor vasculature into the tumor interstitium, distribute to the target site, and finally bind the target (Schmidt et al., 2008). Solid tumors often have high internal pressure, poor vascularization, and an abnormally dense extracellular matrix, limiting the ability of mAbs to both penetrate and exit the tumor (Jain, 2001). To escape targetmediated elimination, a CAR mAb must not only escape intracellular lysosomal catabolism, it must also escape the target site. As the accessibility of the target site decreases, it is likely that the effect of $\mathrm{pH}$-dependent target release on targetmediated elimination will also decrease, giving rise to greater exposure in plasma and tumor. To further support for this hypothesis, plasma and tumor pharmacokinetics by LC-MS/MS demonstrated that $\mathrm{pH}$-dependent binding of $10 \mathrm{H} 6$ resulted in greater plasma and tumor exposure (i.e., AUC) than $\mathrm{pH}$-independent T84.66. It is interesting to note that the data showed a larger difference between $10 \mathrm{H} 6$ and T84.66 in plasma versus tumor exposure (i.e., $\mathrm{AUC}_{\text {plasma,10H6 }} /$ $\mathrm{AUC}_{\text {plasma,T84.66 }}>\mathrm{AUC}_{\text {tumor,10H6}} / \mathrm{AUC}_{\text {tumor,T84.66). Although }}$ this difference has not yet been thoroughly explored, we speculate that this finding reflects differences between $10 \mathrm{H} 6$ and T84.66 with respect to relationships between tumor binding and the efficiency of target-mediated elimination. For example, in the condition where tumor mAb concentrations exceed the $K_{\mathrm{D}}$ for CEA binding, tumor concentrations may be expected to approach a plateau (i.e., where cell-surface CEA is nearly saturated with $10 \mathrm{H} 6$ or T84.66). Owing to the benefit of CAR binding within tumor endosomes, however, the tumor-associated target-mediated elimination of $10 \mathrm{H} 6$ would be expected to be less efficient than that of T84.66. Given the significance of target-mediated elimination of anti-CEA mAb in this model, the reduced efficiency of $10 \mathrm{H} 6$ tumor-associated clearance, relative to T84.66, would explain the observed differences in plasma exposure. Importantly, the magnitude of therapeutic benefit of CAR binding of antitumor mAb may be expected to be dependent on dose and on the pharmacodynamics associated with antitumor effects. Given the saturable nature of tumor binding and tumor-associated antibody elimination, we speculate that CAR binding will provide the greatest benefit for $\mathrm{mAb}$ therapies that act by mechanisms where anticancer activity is achieved at low levels of target occupancy (e.g., antibody-drug conjugates, antibodies acting by antibody-dependent cell cytotoxicity).

Here, a new anti-CEA monoclonal antibody, 10H6, has been developed and characterized. This antibody demonstrates $\mathrm{pH}$-dependent binding, consistent with CAR activity, with a dramatic decrease in CEA-binding as $\mathrm{pH}$ is reduced from 7.4 to 5.0. $10 \mathrm{H} 6$ bound to extracellular domains of CEA on LS174T and $\mathrm{MC} 38^{\mathrm{CEA}+}$ tumor cells. Investigations of $10 \mathrm{H} 6$ pharmacokinetics revealed linear, biexponential disposition kinetics in mice bearing no tumor and in mice bearing CEA- and CEA+ tumors. In contrast, T84.66, a monoclonal antibody of the same isotype as $10 \mathrm{H} 6$ (IgG1k), but with $\mathrm{pH}$-independent CEA binding, demonstrates nonlinear pharmacokinetics in mice bearing $\mathrm{MC} 38^{\mathrm{CEA}+}$ tumors. Furthermore, in a human-derived LS174T tumor model, both antibodies exhibit nonlinear pharmacokinetics (consistent with a lack recycling of murine
IgG by hFcRn). Collectively, the data are consistent with the hypothesis that CAR mAbs offer unique pharmacokinetic advantages over traditional therapeutic antibodies. Clinical application of this strategy will require the development of CAR mAbs with human or humanized Fc domains that enable binding to human FcRn. Humanized versions of $10 \mathrm{H} 6$ may find utility in the treatment of CEA + tumors, with improved disposition and exposure relative to anti-CEA mAbs that exhibit $\mathrm{pH}$-independent binding; however, it is clear that the therapeutic impact of the observed pharmacokinetic advantages of CAR mAb will be dependent on multiple determinants of $\mathrm{mAb}$ efficacy, including the mechanisms and concentration dependencies associated with mAb pharmacodynamics. Further investigation of the pharmacokinetics and pharmacodynamics of anticancer CAR mAb and conjugates appears to be warranted.

\section{Authorship Contributions}

Participated in research design: Engler, Polli, Li, An, Qu, Otteneder, Balthasar.

Conducted experiments: Engler, Polli, Li, An.

Contributed new reagents or analytic tools: Engler, Polli, Li, An, $\mathrm{Qu}$, Balthasar.

Performed data analysis: Engler, Polli, Li, Balthasar.

Wrote or contributed to the writing of the manuscript: Engler, Polli, Li, An, Qu, Balthasar.

\section{References}

Abuqayyas L and Balthasar JP (2012a) Application of PBPK modeling to predict monoclonal antibody disposition in plasma and tissues in mouse models of human colorectal cancer. J Pharmacokinet Pharmacodyn 39:683-710.

Abuqayyas L and Balthasar JP (2012b) Pharmacokinetic mAb-mAb interaction: antiVEGF $\mathrm{mAb}$ decreases the distribution of anti-CEA mAb into colorectal tumor xenografts. AAPS J 14:445-455.

An B, Zhang M, Johnson RW, and Qu J (2015) Surfactant-aided precipitation/onpellet-digestion (SOD) procedure provides robust and rapid sample preparation for reproducible, accurate and sensitive LC/MS quantification of therapeutic protein in plasma and tissues. Anal Chem 87:4023-4029.

Baum RP, Hertel A, Lorenz M, Schwarz A, Encke A, and Hör G (1989) 99Tcmlabelled anti-CEA monoclonal antibody for tumour immunoscintigraphy: first clinical results. Nucl Med Commun 10:345-352.

Beck A, Wurch T, Bailly C, and Corvaia N (2010) Strategies and challenges for the next generation of therapeutic antibodies. Nat Rev Immunol 10:345-352.

Bombski G, Gasiorowska A, Orszulak-Michalak D, Neneman B, Kotynia J, Strzelczyk J, Janiak A, and Malecka-Panas E (2002) Differences in plasma gastrin, CEA, and CA 19-9 concentration in patients with proximal and distal colorectal cancer. Int $J$ Gastrointest Cancer 31:155-163.

Boswell CA, Tesar DB, Mukhyala K, Theil F-P, Fielder PJ, and Khawli LA (2010) Effects of charge on antibody tissue distribution and pharmacokinetics. Bioconjug Chem 21:2153-2163.

Chaparro-Riggers J, Liang H, DeVay RM, Bai L, Sutton JE, Chen W, Geng T, Lindquist K, Casas MG, Boustany LM, et al. (2012) Increasing serum half-life and extending cholesterol lowering in vivo by engineering antibody with $\mathrm{pH}$-sensitive binding to PCSK9. J Biol Chem 287:11090-11097.

Chen J and Balthasar JP (2007) Development and characterization of high-affinity anti-topotecan IgG and Fab fragments, in Handbook of Pharmaceutical Biotechnology (Gad SC ed) pp 835-859, John Wiley \& Sons, Inc., Hoboken, NJ.

Dall'Acqua WF, Kiener PA, and Wu H (2006) Properties of human IgG1s engineered for enhanced binding to the neonatal Fc receptor (FcRn). J Biol Chem 281: 23514-23524.

Datta-Mannan A, Witcher DR, Tang Y, Watkins J, Jiang W, and Wroblewski VJ (2007) Humanized IgG1 variants with differential binding properties to the neonatal Fc receptor: relationship to pharmacokinetics in mice and primates. Drug Metab Dispos 35:86-94.

Ecker DM, Jones SD, and Levine HL (2015) The therapeutic monoclonal antibody market. MAbs 7:9-14.

Garg A and Balthasar JP (2007) Physiologically-based pharmacokinetic (PBPK model to predict IgG tissue kinetics in wild-type and FcRn-knockout mice. $J$ Pharmacokinet Pharmacodyn 34:687-709.

Geisow MJ and Evans WH (1984) pH in the endosome. Measurements during pinocytosis and receptor-mediated endocytosis. Exp Cell Res 150:36-46.

Goetze AM, Liu YD, Zhang Z, Shah B, Lee E, Bondarenko PV, and Flynn GC (2011) High-mannose glycans on the Fc region of therapeutic IgG antibodies increase serum clearance in humans. Glycobiology 21:949-959.

Goldstein MJ and Mitchell EP (2005) Carcinoembryonic antigen in the staging and follow-up of patients with colorectal cancer. Cancer Invest 23:338-351.

Hammarström S (1999) The carcinoembryonic antigen (CEA) family: structures, suggested functions and expression in normal and malignant tissues. Semin Cancer Biol 9:67-81. 
Hinton PR, Johlfs MG, Xiong JM, Hanestad K, Ong KC, Bullock C, Keller S, Tang MT, Tso JY, Vásquez M, et al. (2004) Engineered human IgG antibodies with longer serum half-lives in primates. J Biol Chem 279:6213-6216.

Igawa T, Ishii S, Tachibana T, Maeda A, Higuchi Y, Shimaoka S, Moriyama C, Watanabe T, Takubo R, Doi Y, et al. (2010) Antibody recycling by engineered $\mathrm{pH}$-dependent antigen binding improves the duration of antigen neutralization. Nat Biotechnol 28:1203-1207.

Jain RK (2001) Delivery of molecular and cellular medicine to solid tumors. Adv Drug Deliv Rev 46:149-168.

Junghans RP and Anderson CL (1996) The protection receptor for IgG catabolism is the beta2-microglobulin-containing neonatal intestinal transport receptor. Proc Natl Acad Sci USA 93:5512-5516.

Junghans RP and Waldmann TA (1996) Metabolism of Tac (IL2Ralpha): physiology of cell surface shedding and renal catabolism, and suppression of catabolism by antibody binding. J Exp Med 183:1587-1602.

Kraeber-Bodéré F, Rousseau C, Bodet-Milin C, Ferrer L, Faivre-Chauvet A, Campion L, Vuillez JP, Devillers A, Chang CH, Goldenberg DM, et al. (2006) Targeting, toxicity, and efficacy of 2 -step, pretargeted radioimmunotherapy using a chimeric bispecific antibody and 131I-labeled bivalent hapten in a phase I optimization clinical trial. J Nucl Med 47:247-255.

Kuus-Reichel K, Grauer LS, Karavodin LM, Knott C, Krusemeier M, and Kay NE (1994) Will immunogenicity limit the use, efficacy, and future development of therapeutic monoclonal antibodies? Clin Diagn Lab Immunol 1:365-372.

Mach J-P, Buchegger F, Forni M, Ritschard J, Berche C, Lumbroso J-D, Schreyer M, Girardet C, Accolla RS, and Carrel S (1981) Use of radiolabelled monoclonal antiCEA antibodies for the detection of human carcinomas by external photoscanning and tomoscintigraphy. Immunol Today 2:239-249.

Markley JL (1975) Observation of histidine residues in proteins by nuclear magnetic resonance spectroscopy. Acc Chem Res 8:70-80.

Motulsky H (1995) Intuitive Biostatistics, Oxford University Press, New York.

Nedelman JR, Gibiansky E, and Lau DT (1995) Applying Bailer's method for AUC confidence intervals to sparse sampling. Pharm Res 12:124-128.

Nouri-Nigjeh E, Zhang M, Ji T, Yu H, An B, Duan X, Balthasar J, Johnson RW, and Qu J (2014) Effects of calibration approaches on the accuracy for LC-MS targeted quantification of therapeutic protein. Anal Chem 86:3575-3584.

Ober RJ, Radu CG, Ghetie V, and Ward ES (2001) Differences in promiscuity for antibody-FcRn interactions across species: implications for therapeutic antibodies. Int Immunol 13:1551-1559.

Orava EW, Cicmil N, and Gariépy J (2010) Delivering cargoes into cancer cells using DNA aptamers targeting internalized surface portals. Biochim Biophys Acta 1798:2190-2200. Reichert JM (2012) Marketed therapeutic antibodies compendium. MAbs 4:413-415. Reichert JM (2016) Antibodies to watch in 2016. MAbs 8:197-204.

Reichert JM (2017) Antibodies to watch in 2017. MAbs 9:167-181.

Robbins PF, Kantor JA, Salgaller M, Hand PH, Fernsten PD, and Schlom J (1991) Transduction and expression of the human carcinoembryonic antigen gene in a murine colon carcinoma cell line. Cancer Res 51:3657-3662.

Rowland GF, Simmonds RG, Gore VA, Marsden CH, and Smith W (1986) Drug localisation and growth inhibition studies of vindesine-monoclonal anti-CEA conjugates in a human tumour xenograft. Cancer Immunol Immunother 21:183-187.
Schmidt MM, Thurber GM, and Wittrup KD (2008) Kinetics of anti-carcinoembryonic antigen antibody internalization: effects of affinity, bivalency, and stability. Cancer Immunol Immunother 57:1879-1890.

Schoch A, Kettenberger H, Mundigl O, Winter G, Engert J, Heinrich J, and Emrich T (2015) Charge-mediated influence of the antibody variable domain on FcRndependent pharmacokinetics. Proc Natl Acad Sci USA 112:5997-6002.

Shah DK and Balthasar JP (2014) PK/TD modeling for prediction of the effects of $8 \mathrm{C} 2$, an anti-topotecan mAb, on topotecan-induced toxicity in mice. Int J Pharm 465:228-238.

Shi ZR, Tsao D, and Kim YS (1983) Subcellular distribution, synthesis, and release of carcinoembryonic antigen in cultured human colon adenocarcinoma cell lines. Cancer Res 43:4045-4049.

Shin MC, Zhang J, Min KA, He H, David AE, Huang Y, and Yang VC (2015) PTDmodified ATTEMPTS for enhanced toxin-based cancer therapy: an in vivo proof-ofconcept study. Pharm Res 32:2690-2703.

Swartz M and Krull IS (2012) Handbook of Analytical Validation, CRC Press, Boca Raton, FL.

Treish I, Schwartz R, and Lindley C (2000) Pharmacology and therapeutic use of trastuzumab in breast cancer. Am J Health Syst Pharm 57:2063-2076.

Urva SR and Balthasar JP (2010) Target mediated disposition of T84.66, a monoclonal anti-CEA antibody: application in the detection of colorectal cancer xenografts. MAbs 2:67-72.

Urva SR, Yang VC, and Balthasar JP (2009) Development and validation of an enzyme linked immunosorbent assay for the quantification of carcinoembryonic antigen in mouse plasma. $J$ Immunoassay Immunochem 30:418-427.

Urva SR, Yang VC, and Balthasar JP (2010) Physiologically based pharmacokinetic model for T84.66: a monoclonal anti-CEA antibody. J Pharm Sci 99:1582-1600.

Vaughn DE and Bjorkman PJ (1998) Structural basis of pH-dependent antibody binding by the neonatal Fc receptor. Structure 6:63-73.

Wanebo HJ, Rao B, Pinsky CM, Hoffman RG, Stearns M, Schwartz MK, and Oettgen $\mathrm{HF}$ (1978) Preoperative carcinoembryonic antigen level as a prognostic indicator in colorectal cancer. $N$ Engl J Med 299:448-451.

Wani MA, Haynes LD, Kim J, Bronson CL, Chaudhury C, Mohanty S, Waldmann TA Robinson JM, and Anderson CL (2006) Familial hypercatabolic hypoproteinemia caused by deficiency of the neonatal Fc receptor, FcRn, due to a mutant beta2microglobulin gene. Proc Natl Acad Sci USA 103:5084-5089.

Yeung YA, Leabman MK, Marvin JS, Qiu J, Adams CW, Lien S, Starovasnik MA and Lowman HB (2009) Engineering human IgG1 affinity to human neonatal Fc receptor: impact of affinity improvement on pharmacokinetics in primates. $J$ Immunol 182:7663-7671.

Zheng C, Feng J, Lu D, Wang P, Xing S, Coll JL, Yang D, and Yan X (2011) A novel anti-CEACAM5 monoclonal antibody, CC4, suppresses colorectal tumor growth and enhances NK cells-mediated tumor immunity. PLoS One 6:e21146.

Address correspondence to: Joseph P. Balthasar, University at Buffalo, 452 Kapoor Hall, University at Buffalo, Buffalo, NY 14214-8033. E-mail: jb@ buffalo.edu 